\title{
Property Enforcement as Organized Consent
}

\author{
Benito ARRUÑADA \\ Department of Economics and Business \\ Universitat Pompeu Fabra \\ Mail: Trias Fargas, 25. 08005-Barcelona, Spain \\ E-mail: benito.arrunada@econ.upf.es \\ Http://www.econ.upf.es/ arrunada.
}

Journal of Law, Economics, and Organization vol. 19 issue 2, pp. 401-44 


\section{Contents}

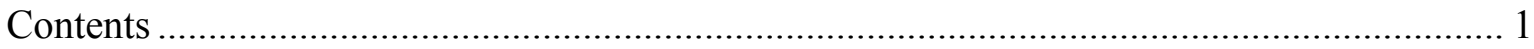

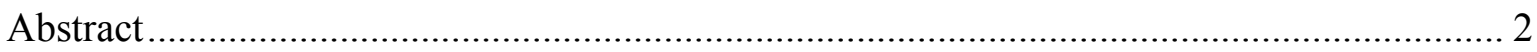

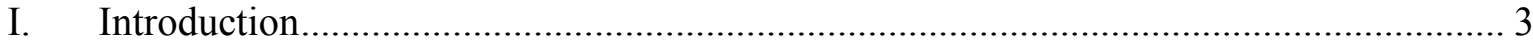

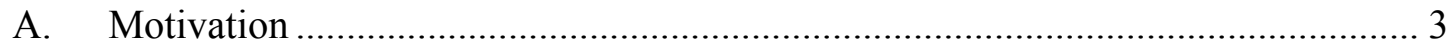

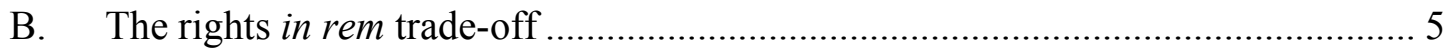

C. Privacy of rights as a benchmark ……........................................................... 7

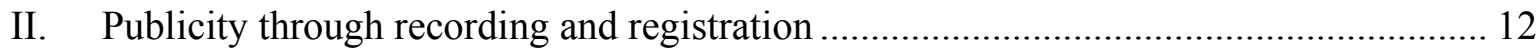

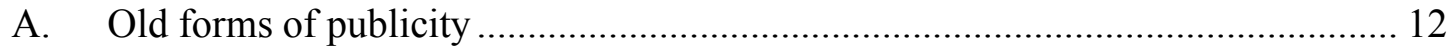

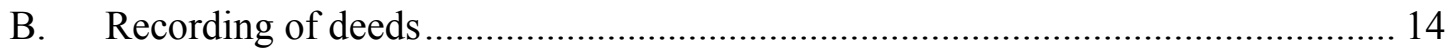

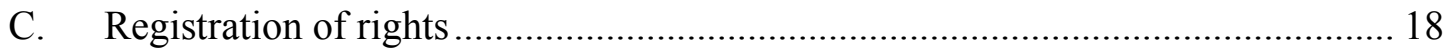

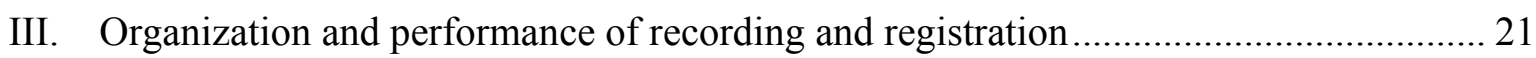

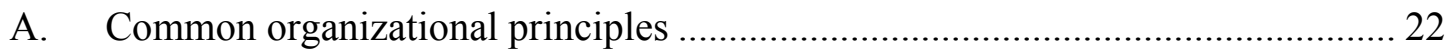

1. Competition as a safeguard of quality in private contracting .................... 22

2. Monopoly as a safeguard of independence when third parties are

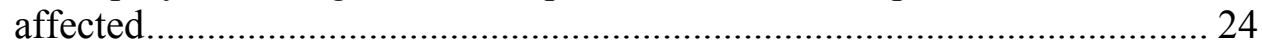

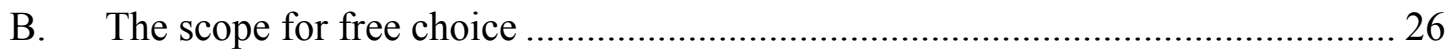

1. Freedom to switch between privacy and publicity …................................. 28

2. Freedom to switch between recording and registration ............................. 29

C. Performance: promised and delivered............................................................ 30

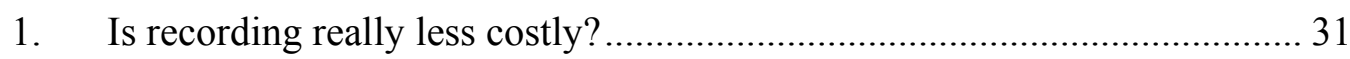

2. Is registration really more effective? ................................................. 33

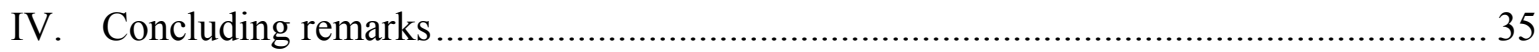

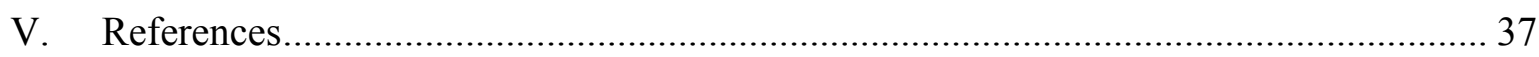

Figure 1. Comparison of privacy, recording and registration............................................. 45

Table 1. Number of registerable property rights in 42 jurisdictions..................................... 46 


\title{
Property Enforcement as Organized Consent
}

\author{
Benito ARRUÑADA
}

\begin{abstract}
\end{abstract}
This article develops and tests a theory of the institutions that make property rights viable, ensuring their enforcement, mobilizing the collateral value of assets and promoting growth. In contrast to contractual rights, property rights are enforced in rem, being affected only with the consent of the right holder. This ensures enforcement but is costly when multiple, potentially colliding rights are held in the same asset. Different institutions reduce the cost of gathering consents to overcome this trade-off of enforcement benefits for consent costs: recording of deeds with title insurance, registration of rights and even a regimen of purely private transactions. All three provide functionally similar services, but their relative performance varies with the number of transactions, the risk of political opportunism and regulatory consistency. The analysis also shows the rationality of allowing competition in the preparation and support of private contracts while requiring territorial monopoly in recording and registration activities, this to ensure independence and protect third parties.

Keywords: property rights, enforcement, land titles, transaction costs, recording, registration. JEL: D23, K11, K12, L85, Q15.

\footnotetext{
* The author thanks Lee J. Alston, Yoram Barzel, Lynn M. Fisher, William W. Fisher, Andrew U. Frank, Nuno Garoupa, Fernando Gómez-Pomar, Philip E. Keefer, Fredrick M. Kerr, Gary D. Libecap, Dean Lueck, Carl H. Lyttkens, Thomas W. Merrill, Pam O’Connor, Joyce D. Palomar, Richard Pipes, Raúl Viedma, two anonymous referees and participants at several seminars and conferences for their comments, Ana Estrada for her research assistance, and, most especially, Fernando Méndez and Celestino Pardo for their help in understanding the intricacies of property law. Usual disclaimers apply. This work has received financial support from the MCYT, an agency of the Spanish Government, through grants SEC99-1191 and SEC2002-04471-C02-02.
} 


\section{Introduction}

\section{A. Motivation}

Rights on real property are critical for economic development. Land is not only an important resource in itself; it also provides the best collateral, reducing the transaction costs of credit. With this in mind, international aid organizations have been promoting land administration projects in most developing and former Socialist countries. The results have been disappointing, however, and the net benefits of such projects are being questioned. ${ }^{1}$ Simultaneously, land conveyance systems have been subject to criticism in developed countries, as professional structures seem ill adapted to prevailing market conditions. A certain gap between the demands of practitioners and the scientific supply of solutions seems to exist. ${ }^{2}$ Despite developments in law and economics and property rights that provide powerful concepts and analyses, such as those on the role of possession and adjudication rules by Epstein (1979, 1987), Baird and Jackson (1984), Levmore (1987), Rose (1988), Miceli and Sirmans (1995), and Miceli, Sirmans and Turnbull (1998, 2000), most other work has failed until recently to fully consider the core nature of property law. ${ }^{3}$ Similarly, most studies on the empirical effects of property rights treat titling as a 'black box, ${ }^{4}$ so results tend to be too general to provide much help to experts in the field who, because of this lack of theory, are forced to define 'best practice' standards by induction.

This tendency has recently changed, with the efforts to develop a formal integrated theory of liability and property rules by Ayres et al. (1995a, 1995b, 1997, 2001), Kaplow and Shavell (1995, 1996); and the analyses on the nature of property rights and the legal constraints on their creation by Heller (1998), Buchanan and Yoon (2000), Merrill and Smith (2000, 2001a, 2001b) and Hansmann and Kraakman (2002), among others. These works are extremely valuable in developing a better general understanding of property rights, as will be discussed below. However,

\footnotetext{
1 These projects have received extensive coverage, as discussed in Braverman, Brooks and Csaki (1993) and World Bank (2001).

2 See, on this, for example, de Soto (2000).

3 Merrill and Smith (2001b) argue that different economic analyses of property rights, rooted in Coase (1960) and represented by Calabresi and Melamed (1972), Cooter (1985) and Barzel (1989), overlook rights in rem and, as a consequence, a substantial part of property law.

4 On the effects of property rights on land in development, see Anderson and Lueck (1992), Besley (1995), Alston, Libecap and Schneider (1996), Atwood (1990), Place and Hazell (1993), Place and Migot-Adholla (1998), and Larson, Palaskas and Tyler (1999).
} 
regarding the organizational design of supporting institutions, they are necessarily limited by their legal emphasis and general scope. ${ }^{5}$

Further connections between law, economics and organizational analysis seem necessary to fill the gap. This article contributes in this direction by providing an understanding of the legal processes and their supporting organizational structures. Using an analytical framework derived from the conventional connection between property rules and transaction costs (in the spirit of Calabresi and Melamed, 1972), it examines why, when and how modern legal systems enforce property rights in land. By revealing the functional similarity of different systems, it shows how they accomplish the basic function of property law institutions: the organization of the consent process inherent to the enforcement of property rights as rights in rem. ${ }^{6}$ It then identifies the common organizational patterns shared by the different systems as well as their differences in design and relative performance. Finally, the analysis answers some fundamental questions concerning the reform of these systems in developed countries and illuminates the establishment of new systems in the developing world.

Empirical evidence comes mainly from a comparison of five jurisdictions in both the Common and Civil Law traditions. This provides diversity of perspectives, valuable even if there is little correspondence between these traditions and the solutions adopted. Both the system of deed recording, used in France and the US, and that of registration of rights, used in England, Germany and Spain, are often employed in countries under both legal traditions, an assertion that is confirmed in Section II.B by an econometric test run over a sample of 42 jurisdictions. These two systems present obvious differences: under deed recording, there is no mandatory public 'cure' or 'purge' of transactions ex ante, as there is under registration. However, both systems are shown to be functionally similar: recording makes possible private assurance activities that in fact provide voluntary ex ante purging of rights in rem. Historical evidence on legal institutions is also used to fill in the gaps in the current institutional continuum and thus illustrate problems that are absent in contemporary systems. As in any effort to identify the essential structure of complex institutions, plenty of detail is intentionally suppressed. In particular, US jurisdictions are represented by their most common system and the analysis focuses on steady-state paradigms, with less emphasis on hybrid forms and the nuances and dynamics of existing systems.

The article is structured as follows. The remaining sections of this first Part formulate the theoretical framework and analyze the problems created by private contracting of property rights,

\footnotetext{
5 Or, in other cases, by their focus on specific assets, such as artists' 'moral' rights (Hansmann and Santilli, 1997, 2001) and the role of legal entities in portioning property rights (Hansmann and Kraakman, 2000).

6 A right in rem is claimable against the asset itself and is therefore valid against all people while a contractual right is valid only against a limited number of people, a distinction that will be further clarified below.
} 
which is the legal regime used here as reference. Part II explains the structure and functional equivalence of the institutional solutions based on publicity of deeds and rights. This yields some lessons for the organization and relative performance of the two modern forms of publicity, recording of deeds and registration of rights, which are explored in Part III. Part IV concludes by sketching potential extensions of the analysis.

\section{B. The rights in rem trade-off}

This work is based on the essential legal distinction between property and contractual rights which are often lumped together under the 'property rights' label in the economics literature. ${ }^{7}$ Rights on land or many other assets can be enforced as property rights, iura in rem, claimable against the asset itself and therefore valid against all persons, erga omnes. Property rights are said to 'run with the land,' meaning that they survive unaltered through all kinds of transactions and transformations dealing with other rights on the same parcel of land or on a neighboring parcel. For example, the mortgagee keeps the same claim on the land even after the mortgagor sells it. Property rights oblige all people: the new owner who has purchased the land is obliged to respect both the mortgage and, in particular, the right to foreclose in case the guaranteed debt is not paid. Enforcement of a property right is independent of who holds other rights on the same asset.

Alternatively, rights on assets can be contractual rights, enforceable against a specific person, inter partes. To clarify the difference between property and contractual rights, consider what happens in another case, that of a lease of land, this being a right that in many jurisdictions may be structured as either a contractual or a property right. Assume that the land is sold during the life of the lease. If the lease is a contractual right, the lessee loses the right of occupation, and gains instead a contractual right against the lessor. However, if the lease is a property right, the lessee keeps the right of occupation. It is then the land purchaser who may have a contractual right against the seller, if the sale was made free of leases. The buyer is subrogated into the seller's position. There is no change to the lease, which has run with the land from the seller to the buyer, surviving intact after the sale.

The analytical framework will be based on a truism that is implicit in this characterization of property rights. ${ }^{8}$ When the law enforces a right as a right in rem, consent of the right holder is

\footnotetext{
${ }^{7}$ See, for instance, Barzel (1989).

8 This builds on the old idea that if an entitlement is protected by a property rule, it can lead to high transaction costs. These costs can be avoided by using weaker protections like liability rules, for which non-consensual takings are allowed. The trade-off is between the strength of one's rights and their transferability at low cost. Starting with Calabresi and Melamed (1972), the trade-off is more or less explicit in, among many others, Baird and Jackson (1984), Epstein (1987), Levmore (1987) and Rose (1988), as
} 
required for the right to be affected, that is, damaged, in any way. ${ }^{9}$ This requirement of consent provides precious enforcement benefits for rights on durable and unmovable assets and especially for rights on land, an asset that cannot be removed and is less subject to abuse than most other assets. ${ }^{10}$ On the other hand, the enforcement of contractual rights depends on the availability, resources and legal status of persons, who are mobile and may become unavailable or judgment proof when obliged to pay. For durable assets, a property right is therefore much more valuable than a contractual right having the same content - that is, when the only difference between them is that the latter lacks in rem enforceability.

These enforcement benefits come at a cost, however - transactions among parties do not convey property rights with the promised in rem extent until all affected right holders have consented. In other words, to produce perfect property - that is, in rem-rights, some kind of secondary contracting has to take place between the parties and each of the affected right holders in order for the latter to give their consent. Many institutions in the field of property law are designed to make these second 'contracts' with affected right holders possible. Consent can be given explicitly, by private agreement, declaring to a register or in court proceedings, as well as implicitly, by the simple passage of time. Consent can also be produced ex ante, at the moment the relevant transaction takes place. Consequently, the rights resulting from the transaction will be free of uncertainty as to whom the true legal right holder is and as to their precise nature. Alternatively, consent can be postponed, and the relevant transaction then produces rights which are burdened with the survival of any property rights whose right holders have not yet consented.

In any case, without the consent of affected right holders, transactions produce a mix of property and contractual rights: property - in rem - effects to the extent compatible with the surviving property rights held by others, and contractual rights for the difference. ${ }^{11}$ The proportion of property and contractual rights in the mix varies with the kind of conflicting right. In the

well as in more recent works which have mostly focused on the role of the numerus clausus of property rights, such as Heller (1999), Merrill and Smith (2000), and Hansmann and Kraakman (2002).

9 This article uses the terms 'consent' and 'consent costs' instead of the more generic 'transaction' costs to distinguish between the costs of the private transaction between seller $A$ and buyer $B$, and the costs of 'transacting' to achieve the consent of all third parties $C, D, \ldots Z$ holding property rights on the same plot of land.

10 Departure from the assumption of asset survival introduces confusion in the analysis of property rights. For example, when Hansmann and Kraakman (2002: S410) criticize the standard definition of rights in rem (those 'good against all the world'), they present the case in which a painting is damaged by a third party tortfeasor. The case is ill-suited to their query about the contractual or property nature of the painter's rights to sue under different arrangements, because all rights under consideration are necessarily contractual, due to the partial destruction of the asset.

11 The gathering of consent would pose a minor problem if only one right were defined for each asset. It is usually efficient, however, that many people hold rights on the same asset in order to reach specialization advantages. In the case of land, it is common to allocate physical possession and legal ownership to different persons, and to define other abstract rights in order to exploit the collateral value of the land. Owners also hold some rights on neighboring land, either individually or through political bodies. (Ellickson [1993] provides a detailed analysis of the variety of property rights on land). In addition, multiple rights can also arise as an unintended consequence of most transactions. In essence, any claim on an asset is a right in rem. 
extreme case of a fraudulent conveyance, the grantee gets only a contractual right against the grantor, who is not the true owner. More generally, any intended property right is in fact partially contractual if an affected right holder keeps a contradictory or concurrent right against it. This is also true of most disputes on title. ${ }^{12}$ Let us assume $A$ sells land to $B$, but $C$ might be the true owner with some probability $\theta$. Until $C$ consents or the uncertainty is somehow resolved, $C$ has a property right and $B$ 's ownership is burdened with that title 'cloud.' (Depending on the specific circumstances, $B$ will also have obtained a lower price or a contractual right against $A$ and/or other participants in the transaction).

Property rights thus face a trade-off with positive and negative effects. On the one hand, they facilitate specialization by ensuring enforcement, given that right holders' consent is required to affect them. However, for the same reason, their survival after conveyance of the asset or any other transformation of rights requires costly institutions and resources in order to organize the process of searching, bargaining and contracting for consent. An obvious cost is that the possibility of hidden property rights increases the information asymmetry between the conveying parties: in the absence of consent from the hidden right holder, the acquired asset is burdened with it and the acquirer has instead a contractual right against the seller. More generally, the need to know which conflicting property rights exist, of finding out who their right holders are, of bargaining with such right holders to obtain their consent and of contracting or somehow formalizing an agreement with them, all increase the costs of transforming and conveying rights. This may in turn hamper investment, trade and specialization.

\section{Privacy of rights as a benchmark}

Under the Roman Law tradition of private conveyance that was dominant in Europe until the 19th century, private contracts on land had in rem effects on third parties even if the parties kept them secret. ${ }^{13}$ In cases of conflict, courts 'established title' (that is, they allocated property and contractual rights) on the basis of evidence on possession and past transactions, whether or not these transactions had remained hidden. This potential enforcement of adverse hidden rights made full consent hard to reach ex ante, hindering trade and specialization. All transactions in land then gave rise, totally or partially, to contractual rights and the enforcement advantage of property rights remained unfulfilled, especially with respect to abstract rights. This can be clearly observed

\footnotetext{
12 The word 'title' often refers to both a legal right, as here, and to the evidence of it. Established practice makes it impossible to avoid this ambiguity, which, for the most part, is easily clarified by context.

13 Certain formalities were required but they aimed to avoid fraud and facilitate the potential future work of the courts - not to provide publicity.
} 
in the functioning of the two sources of evidence traditionally used to establish title under a privacy regime: possession and the chain of title.

First, the use of physical possession as the basis for establishing property rights intrinsically limits specialization, because it is not applicable to abstract rights like ownership and mortgages. ${ }^{14}$ For example, to the extent that possession is used to establish ownership, specialization of ownership and control is hindered - control requires possession, and this subjects owners to the risk of possessors using their position to acquire ownership or convey owners' rights. In such cases, owners will only hold a contractual right against the possessor committing the fraud. Similarly, credit will involve contractual guarantees provided either by the debtor or by the lender. This is because the only way of providing an in rem guarantee to the lender is by transferring ownership and/or possession to him, thus leaving the debtor subject to the lender's moral hazard, safeguarded only by the lender's contractual guarantee, which is weak and costly to produce. Moreover, it is not possible to use the same land to secure debts with several lenders unless third party administration is used.

Second, some of the problems posed by possession are solved by embodying abstract rights such as ownership and liens, and even consent, ${ }^{15}$ in titles. Evidencing rights with the chain of title certainly facilitates the separation of ownership and control. However, acquirers remain fully unprotected against those hidden charges which are not voluntarily contracted, such as judgment and property tax liens. Furthermore, new possibilities for fraudulent conveyance appear (for instance, pre-dating a sale or a mortgage in order to embezzle assets), which again give rise to contractual rights against the fraudulent grantor and the professionals involved in the transaction. ${ }^{16}$ To contain fraud, conveyancing probably tends to develop into professional monopoly. The chain of titles also serves to enforce a security, by depositing the titles with the lender. ${ }^{17}$ However, this burdens the debtor with the lender's moral hazards and causes switching costs that make second

\footnotetext{
14 For a detailed analysis of the role played by possession in the transfer of property rights in different kinds of assets, see Baird and Jackson (1984).

15 Having the granting of consent by those right holders affected included in the title might have been used for a long time. In the Demotic titles used in Ptolemaic Egypt in the period between 650 BCE-30 BCE, the consent of affected right holders (usually the wife and co-heirs of the vendor) was stated in a specific clause (Manning, 1995: 254-55).

16 The pervasiveness of compulsory proof attests to the importance of restraining fraudulent conveyance. Ancient societies even treated deeds and land grants as sacred (Ellickson, 1993: 1329, n. 49). In Egypt, land was transferred by conveying the full chain of titles, and deeds were 'sealed' by a public official (Manning, 1995, 2003, Powelson, 1988: 17-19; Silver, 1995: 125). The use of titles might well have been even older. Practice among the Ewe people showed that titles do not need to be written, not even for using the chain of title as evidence of good title (Lowie, 1920: 223-24). From early times, legal systems also required the presence of witnesses.

17 Evidence of this practice in Mesopotamia dates from the second millennium B.C. (Silver, 1995: 123-24).
} 
mortgages difficult. Transactions on unregistered land in England suffered from some of these difficulties until recently. ${ }^{18}$

Figure 1 represents in parallel the processes used to convey property rights in different legal systems. In all of them, there are, or may be, two contractual stages: first, the private contract between the transacting parties; second, the contracts between the transacting parties - usually the grantor - and the third parties holding rights being affected by the private transaction, by which these third parties consent to the said private transaction. These second 'contracts' are driven by different rationales in each system (voluntary under privacy and recording, mandatory under registration), and use increasingly complete information about which rights are affected and therefore require consent. This information is also processed in a different manner and by a variety of private and public agents who produce different inputs for the contracting process.

Part (a) of the Figure shows the most typical process under a pure privacy regime. Given that, in this case, the courts are willing to enforce in rem rights that may have remained hidden, ex ante examination of title quality is based on potentially incomplete evidence. Understandably, parties in this and all legal systems try to contract relying on the same evidence used by the State to establish title. Under privacy, however, potential in rem enforceability of hidden rights makes it very difficult for the parties to have all the relevant information. In particular, removal of title defects and contradictions as well as any adjustments to the terms of the private contract are informed only by the limited publicity provided by possession and formal conveyance (the chain of title deeds) and the risk the grantor faces when giving title warranties on a defective title. ${ }^{19}$ These warranties create only contractual obligations, however, and grantees have limited possibilities of knowing what they are buying. They in fact acquire residual property rights plus a contractual right against the grantor for the difference between the property rights effectively granted and what the grantor had promised to deliver. ${ }^{20}$ This is applicable to all kinds of property rights. Having been acquired subject to these uncertainties, all of them have a residual character

\footnotetext{
18 For descriptions of the procedures used in these transactions, see, for example, Bostick (1987: 75-76), HMLR (1996: 1) and Sparkes (1999: 76-77, 477). Concentration of agricultural land ownership was probably important in making this system viable despite its shortcomings (see Pottage, 1998). This is consistent with two facts. First, the landed gentry and the solicitors successfully opposed the introduction of registration in the $19^{\text {th }}$ century (Anderson, 1992). Second, registration was finally introduced on a gradual and geographic basis, starting with the city of London in 1897.

19 Already in ancient Babylonia it was common to enhance the security of land transactions including the equivalent of modern eviction warranties of title (Silver, 1995: 124; Ellickson and Thorland, 1995: 383).

20 The terminology here may lead to confusion, because of the use of specific names such as 'title clouds' or 'title defects' for those collisions of rights that do not question ownership. The presence of different names suggests different problems. Both problems are, however, structurally identical because they transform the affected right into a contractual right. This transformation will be total or partial, depending on the nature of the hidden competing right: For example, a buyer may lose all property rights if a hidden owner emerges or only part of them if the hidden right was an easement or a mortgage.
} 
and are complemented by contractual rights - their value will therefore depend on the wealth of the grantors and the enforcement of contractual rights, and they lose in rem efficacy.

In addition to heavier reliance on the courts, through proceedings similar but less secure than the quiet title suit, ${ }^{21}$ parties and legal systems counterbalance this incompleteness of property rights by strengthening contractual rights. Enforcement of these is privately reinforced by having the title warranties underwritten by third parties. In primitive societies, this is mostly done implicitly, by making extended families responsible for their members' debts. ${ }^{22}$ There are also some explicit arrangements of this kind, however. For instance, witnesses are often personally liable on a subsidiary basis. Similarly, contracting specific third party eviction guarantees, a precedent of title insurance, used to be common in England. Public enforcement of contractual obligations is also strengthened, including debtors' prison. ${ }^{23}$ Many societies have relied, until recently, on personal indenture. In some parts of the world, children continue to be used as bonds, and slavery is still a common consequence of unpaid debts. ${ }^{24}$ Without necessarily implying causality, this contrasts with the tendency of more developed legal systems to relax the enforcement of contractual obligations, for example, in personal bankruptcy. ${ }^{25}$

Considering its defects and the current prevalence of publicity, pure privacy seems inefficient and outdated. However, these two judgments have to be qualified, mainly because the net value of publicity might depend on the capacity to control political opportunism and individual rentseeking. In general, publicity will tend to facilitate enforcement, not only of private rights but also of public duties (for instance, the collection of taxes), this facilitation of enforcement being an example of how the state can develop property rights to maximize its own interests. ${ }^{26}$ This may

\footnotetext{
21 As an example, it suffices to mention the role of the 'fine' in England, a simulated lawsuit that allowed the transaction to be entered in the books of the court and made it binding on everybody after a short period of limitation. It was used from the $12^{\text {th }}$ century until 1833 (Kolbert and Mackay, 1977: 241). Similar fictitious judicial procedures are found in very different historical contexts. See, for example, an analysis of a well-known biblical case in Ellickson and Thorland (1995: 385) or the use of amicable litigation in colonial Massachusetts (Konig, 1974: 160-61). These procedures suffer insecurity from their reliance on proclamations. This reliance is most likely inevitable, however, given the hidden character of rights.

22 For most of history, it was common to make sellers' houses liable for the deeds of their members to strengthen the enforcement of personal obligations. (See, for example, Section 9 of the Hammurabi Code in Levmore, 1987: 51).

23 For example, in ancient Rome, where a regime of private land transactions applied until the last centuries of the Empire, the law granted special powers to creditors to control debtors' conduct and mandated double damages for eviction (Jackson, 1908: xxiixxiii; Watson, 1984: 16). Debtors' prison has now disappeared from most jurisdictions. Some criminal enforcement remains alive, however, where debtors can be forced to disclose their assets through an action to recover debt and may even be imprisoned if caught in perjury.

24 See, for example, Hoebel (1979: 107, 231) for primitive societies, Finley (1965) for classic Greece and Rome, and Silver (1995) for the Middle East. "Slave-ships in the 21 st Century?" (The Economist, April $19^{\text {th }} 2001$ ) reports on current debt-slavery practices in West Africa.

25 Perhaps to motivate risk-taking initiatives by providing some limited liability at the personal level or to avoid inefficient signaling, as analyzed by Aghion and Hermalin (1990). A recent historical and empirical analysis of property exemption laws in the United States is provided by Posner, Hynes and Malani (2001).

26 As suggested by Davis and North (1971) and North and Thomas (1973).
} 
have positive or negative social effects depending on the people's capacity to control their government and impede excessive taxation. This potentially negative effect of publicity will only be briefly analyzed in the last sections.

Moreover, rent-seekers may also take advantage of those who publicize their claims, a serious risk in low-security countries where rent seeking may include physical violence in addition to fraudulent sales, or the pursuit of wealthy heiresses by dowry-seeking bachelors, so feared by Victorian fathers. The risk can be partly avoided by applying the traditional, though now apparently old-fashioned, ${ }^{27}$ policy of limiting access to those authorized by right holders and those having, in the opinion of the registrar, a legitimate interest. It goes without saying that public access may also provide benefits. For instance, it affords some additional control of illegitimate accumulation of wealth, as shown in some former Socialist jurisdictions. It is uncertain, however, if open access, instead of limited, regulated access (open to public prosecutors), can contribute much to controlling corruption.

In addition, two other factors should be considered in weighing privacy versus publicity. First, the possibility that inefficient conveyance monopolies may develop to overcome the difficulties posed by a privacy regime. Second, the fact that private conveyance of property rights is not a primitive form of land allocation. On the contrary, it presupposes private and individual rights, while in primitive and many ancient societies the King or God was frequently the owner of most, if not all, of the land while the people enjoyed only conditional rights to use it. These conditional rights were then allocated from above rather than traded, ${ }^{28}$ often through periodic land redistribution and cancellation of debts. ${ }^{29}$ Furthermore, land redistribution is still a crucial element in some land policies. ${ }^{30}$

\footnotetext{
27 The contents of the public files are wholly open to the public in 28 of the 42 jurisdictions reported in UN-ECE (2000).

28 There has been considerable discussion among historians about the strength of property rights in ancient societies. The once dominant denial of the presence of property rights and markets, exemplified by Polanyi (1944), has since been substantially modified by an increasing body of literature, such as that summarized in Silver (1995).

29 Both practices were institutionalized in many primitive tribes (Lowie, 1920: 221), the Inca empire (Espinoza, 1997: 185, 19193), Israel (Leviticus, 25), and classical Greece (Finley, 1953: 62-63). It is even unclear whether the allocation of land in a public ceremony before the Shire of Hundreds ('folk-gemot'), a Saxon practice common before the Norman conquest, was a form of conveyance by publicity, as claimed by Stein and Stone (1991: 1-2), or merely signaled the allocation of land from above, as argued by Kolbert and Mackay (1977: 238).

30 See, for example, the case of Brazil in Alston, Libecap and Mueller (1999: 1-80). This issue is highly relevant for creating effective institutions in developing countries. For instance, perfect land registration will not encourage the use of land as security for credit if taking possession of the land after default is practically impossible, as may well happen in areas with closely-knitted groups. However, episodes such as the US's farm foreclosure moratorium, analyzed by Alston (1984), show how deep-rooted these issues are with respect to rural land even in developed economies. Furthermore, environmental and land uses regulation has given a new twist to the problem.
} 


\section{Publicity through recording and registration}

Whatever the palliatives being applied, the costs of contracting property rights under a regime of pure privacy are such that most, if not all, modern systems of property law opt to reduce such costs by constraining contractual freedom in ways that depart substantially from the standards applied in other fields of law. In essence, the law induces or requires the publicity of contracts as a prerequisite for them to attain in rem effects. If they keep their rights private, right holders lose or risk losing in rem effects. Private contracts may create obligations among the parties but do not bind third parties - all other right holders and, especially, potential future buyers and lenders. Publicity therefore facilitates the search for which property rights are alive, making it possible to reach consent ex ante, purging titles, and reducing information asymmetries between the parties.

Specific laws vary substantially, however, with respect to how and when any contradiction with other property rights must be purged by obtaining the consent of the holders of these affected rights. This second 'contract' can take place either immediately after the private contract, ex ante, or be postponed indefinitely to some time in the future. When ex ante, it can be either compulsory and total or voluntary and, in this case, total or partial. Jurisdictions also differ in the kind of publicity they provide, which may consist of the deeds evidencing potentially contradictory claims or of the property rights themselves. There is also a logical adaptation of the specific devices needed to produce publicity in each environment, the set of rights enforced as property rights and the adjudication rules in cases of disputed title. The analytical framework makes sense of most of these variations in both old and modern systems.

\section{A. Old forms of publicity}

Perhaps the simplest way of providing publicity is by marking the assets. Moreover, the symbolic nature of marking makes it especially suitable for abstract rights, such as ownership and security interests. This explains why it has been used extensively for enforcing ownership in the absence of possession, as in valuable movables such as livestock, automobiles, books and even spouses (wedding rings are only a pale remnant of the variety of devices traditionally used to 'give notice' of marital status). More revealing still is the use of marks to disclose security interests in land. In classical Athens, a slab, known as horos, was posted on the land itself, 31 to be removed

31 See Finley (1952). Posting of notices was still recently used to claim land in the US Far West (Anderson and Hill, 2002). 
only by releasing the encumbrance. These horoi contained the essential data of the encumbrance (always, the nature of the horos as security and more often, but not always, the existence of a written agreement, the name of the creditor and the amount of the debt) and, in some cases, the name of the person who kept the document of the transaction, supposedly to make it possible for third parties to collect more information. This system was one of the first to make an hypotheca possible - namely, the use of land as collateral without temporarily transferring ownership or possession to the lender.

Another simple way of providing publicity is by requiring conspicuous contractual procedures. It is well known that, after 1066, English conveyances followed the continental practice of delivering possession through a ritual known as livery of seisin. In essence, the grantor gave the grantee a clod of earth of the land, a twig or a key and loudly said he was conveying the estate. Several features support the idea that this ceremony had a publicity function. First, it took place on the land or looking at the land. Second, numerous witnesses were required and they, originally, had to be neighboring right holders. Lastly, the fact that, until the Statute of Uses (1535), people preferred to contract uses as a way of avoiding the livery of seisin and thus escaping taxation shows that it gave publicity to tax collectors. Admittedly, this publicity element was diluted later on, as the delivery of deeds substituted the delivery of land (see, Kolbert and Mackay [1977: 23839]). Also, neighbors were no longer necessary, credible witnesses being used instead. ${ }^{32}$ Certainly, a more or less complementary function of any contractual ceremony is to provide evidence of the contract for the parties themselves. Requiring witnesses seems suited to this purpose. The point is, however, that there was also an element of publicity in this ceremony. ${ }^{33}$ The publicity function was even clearer in the practices followed in other regions of Europe, where laws mandated sophisticated procedures of publicity 'before the church' and 'at the gate of town walls' for rural and urban land, respectively, as well as some judicial registration. ${ }^{34}$ The requirements of repeated proclamations and the existence of a waiting period for the contract to reach in rem effects cannot be explained only as providers of evidence. They seem specifically designed to provide publicity and to purge titles, resembling the marriage contract that developed about the same time and the later judicial purge. ${ }^{35}$

\footnotetext{
32 According to Blackstone (1765-69: 315-16).

33 Available evidence on land transactions in Babylonia may be interpreted in a similar fashion. There has been controversy as to whether the 'secondary sellers' present in them are really sellers or mere witnesses (Silver, 1995: 122-27]). An intermediate interpretation seems more sensible: even if not strictly speaking sellers, they might have been holders of affected rights. Their presence in the transaction would assure that pertinent notice had been given to them and they gave their consent. This kind of practice could also be related to the custom of paying 'witnesses' found in some primitive tribes (Diamond, 1975: 259).

34 See, for France, Patault (1989: 205-208) and, for some Hanseatic German cities and Spanish kingdoms, Oliver (1892).

35 Ellickson and Thorland (1995: 383-84) summarize the historical evidence on similar forms of publicity in the ancient societies of the Middle East, dating back to around $2500 \mathrm{BC}$.
} 
The theory fits in with historic developments since the effectiveness of these old practices for reaching consent and purging property rights is greater when transactions take place between neighbors, as was common in rural societies. For neighbors, it is easy to notice announcements and public deals or to police the horoi (these were also made conspicuous by the small size of the plots), especially for the kinds of rights common in rural societies, many of which were linked to family matters. The argument is consistent with the changes mentioned in the livery of seisin. It is also confirmed by the different effects of publicity 'before the church,' which was immediate for those right holders who were present but was delayed for one year and one day for those absent. As in many other contexts, ${ }^{36}$ trading between strangers required different supporting institutions. It was not by chance that trading cities in the late Middle Ages were the first to enact effective registration systems (the case of the German Hanseatic cities of Hamburg and Bremen) and demand them from their Crowns. ${ }^{37}$

\section{B. Recording of deeds}

In their current form, recorders of deeds have been used since the 19th century in most of the US, part of Canada, France and some other countries, most of them having a French legal background. ${ }^{38}$ They enroll and keep private contracts ('title deeds') and thus provide evidence on property claims. This evidence is used by the courts to allocate property rights ex post - after litigation. Furthermore, courts apply a non-standard priority rule. When deciding on a conflict with third parties, they determine the priority of claims from the date of recording in the public office and not from the date of the contract. 39

\footnotetext{
36 North (1990) emphasizes the difference between transacting within a group of neighbors and between unknown, anonymous traders.

37 In addition to the manorial registers kept in medieval times, the main precedent of modern registration is the old German institution of Auflassung, in which documents on the conveyance were presented and examined by the town council and later the court before being noted in a territorial register. However, hints of land registration activities by palaces and temples date from the third millennium B.C. in Babylonia (Silver, 1995: 126-27) and the State kept a register of land in Egypt as early as 2350 B.C. (Powelson, 1988: 17). The role played by these registers in land allocation, land private conveyance and taxation is open to discussion, however.

38 Among the earliest attempts are the Statute of Enrollments issued by Henry VIII in 1535 but never enforced, and the Massachusetts 1640 recording act.

39 This change in the priority rule seems necessary to avoid incomplete recording, which hampered many of the first recording systems. This happened for instance with the Scottish Register of Sasines between 1503 and 1693 (Kolbert and Mackay, 1977: 280-84), the French Conservation des Hypothèques between 1798 and 1855 (Weill, 1979: 547-52) and the Spanish Contadurias de Hipotecas between 1768 and 1861 (Oliver, 1892). Though a necessary condition, priority may not be sufficient, however. For instance, it has been interpreted that the Statute of Enrollments and the Massachusetts 1640 recording act established a clear priority rule based on the recording date that was similar to present-day 'race' statutes (Rose, 1988: 586-87). The use of the priority rule in the these laws is open to question, however. The Statute of Enrollments was never enforced. In Massachusetts, since 1648, recording was required only when the grantor remained in possession and the main means of securing title was through judicial actions (Konig, 1974: 147-64).
} 
This priority rule effectively motivates parties to record from fear of losing title through, for example, a wrongful second sale. ${ }^{40}$ If such a second sale were recorded first, it would gain priority over the first one. Consequently, all relevant evidence on property rights is publicly available by inspecting both the public records and the land itself. ${ }^{41}$ From the point of view of third parties, the record, in principle, is complete (Part [b] of Figure 1). ${ }^{42}$ Some other claims may not be recorded and may well be binding for the parties conveying them, but these hidden claims have no effect on third parties.

It is therefore possible to produce information on the quality of title ('title reports') by having an expert examine all relevant deeds (those that have been recorded) and not only those deeds in the grantor's chain of title. If there is sufficient demand, a whole industry will develop to supply these title assurance services. This may take different forms: notaries public in France and abstractors, attorneys, title insurance agents and title insurance underwriters in the US. To motivate diligence and technological innovation, and to spread remaining risks, a standard of strict liability ('title insurance') tends to be applied to this activity. ${ }^{43}$ Title reports substantially reduce information asymmetry between the parties. Defects derived from title clouds of any kind can therefore be removed before contracting, obtaining the consent of the affected third parties. If not removed, the grantee will not transact or will insist on modifying the content of the private contract, reducing the price or including additional warranties, in compensation for the survival of property rights that are contradictory to those that figured in the preliminary contract.

Contractual and judicial procedures are also used to remove title defects. Compared to privacy, deed recording provides more possibilities for contracting the removal of defects, because defects are better known to buyers and insurers. The identification of right holders also makes more secure the functioning of summary judicial hearings that serve to reduce bargaining costs in complicated cases. These summary hearings continue to exist today in the judicial purge used in France and the US 'quiet title suit.' The existence of such a court-ordered purging possibility also

\footnotetext{
40 Notice that this rationale does not rely on information or prevention advantages held by the first acquirer. Compare, for instance, to the argument given by Ellickson and Thorland (1995: 386, n. 378) who claim that "[the prevalence of good faith acquirers over prior hidden claims] is efficient because a party who first acquires an interest has far better information and ability to prevent double-dealing than does a subsequent purchaser for value".

41 In most jurisdictions, it is also necessary to inspect the land to know about physical possession. This inspection provides actual notice as to the existence of a claim or right. The priority rule also varies substantially and is usually subject to good faith or qualified by buyer knowledge. See Baird and Jackson (1984) and Epstein (1987: 7-19). In the present work, these complementary sources of evidence are sidelined to focus on the role of recorders and registers. In addition to tractability, there is another important reason for this abstraction: being observable, most unrecorded interests held by individual private parties provide, by their very nature, information that makes purging them ex ante a relatively easy task.

42 This ideal completeness of the public record has often remained unfulfilled due to all sorts of organizational and legal problems. See, for instance, Cross (1957) or Straw (1967) on the typical problems of US records.

43 Arruñada (2002) compares the role of title insurance under recording and registration.
} 
stimulates affected parties to reach an agreement privately (see, Cabrillac and Mouly [1997: 73240]).

Despite private incentives to purge rights ex ante, the public record may, however, contain evidence on potentially contradictory rights. The recording office is obliged by law to accept all deeds respecting certain formal requirements, whatever their legality. ${ }^{44}$ It will therefore contain potentially three kinds of deed. First, those resulting from private transactions made without previous examination. Second, those granted after an examination but without having defects removed. Finally, those that define purged and non-contradictory property rights. Experts examining the title of a parcel do not know a priori which of these kinds of deed are recorded concerning it. For each transaction, it is therefore necessary to examine all deeds dealing with that parcel in the past. The cost of examining the deeds can be reduced with proper organization of the register, however. This explains the steps taken in 1955 to create the fichier immobilier in the French register and to forbid recording a deed if the grantor's title is not recorded. When public records are poorly organized, it has been useful to build privately-owned, indexed databases (US 'title plants') that replicate public records in a more complete, reliable and accessible manner. Fundamental improvements are tract indexes to locate the relevant information fast and safely, and a daily transfer and abstracting of relevant data. Computerization of land records, which allows searching by tract, might reduce this need in the future.

The analysis is consistent with the two main features of the law applied in jurisdictions with recording of deeds: adjudication using a rule of property, and greater freedom to structure property rights privately.

First, disputes on title are solved using a property rule. If the seller's right is shown to be defective, the buyer loses the property right to the benefit of the true owner. The buyer is then left with contractual rights against the seller, the title examiner and/or the title insurer. This motivates buyers and, indirectly, all parties to the private contract to produce information and gather the consent of affected right holders ex ante. Specialists, such as US title insurers and French notaries, play the essential role in mainly eliminating — not merely spreading — risks. The risk elimination function of these specialists is clearly shown by the basic numbers of the US title 'insurance' industry. The low ratio of losses to revenue (7.9 percent in 1980-94) provides a measure of its relatively small insurance element. ${ }^{45}$

\footnotetext{
44 For example, articles 27201 of the California Government Code, 291 of the New York Real Property Law and 2146-56 of the French Civil Code.

45 For a transaction costs explanation of title insurance, see Arruñada $(2001,2002)$. Compare Baker et al., who take insurance premiums as a proxy of ex post risk, hoping "to capture the expected cost of a defect, which equals the probability of an error occurring in the title record times the cost of repairing the defect" (2002: 13).
} 
Second, the argument predicts that, under recording, enforcement of property rights will be comparatively unconstrained by the legal system - that is, parties will be relatively free to define the rights that they want to have enforced in rem. In terms more often used in Civil Law, the numerus clausus (closed number) of property rights will be larger. ${ }^{46}$ This greater freedom makes sense when considering that this definition is only in rem to the extent that it does not conflict with other rights - any such conflicts will be resolved later, if ever. This hypothesis is confirmed by the econometric model reported in the first four columns of Table 1, based on international survey data. It shows that the estimated number of in rem rights (namely, the Number of Property Rights variable) is significantly higher in jurisdictions with recording of deeds (proxied by the Recording variable) than in those with registration. The model also shows that the number of property rights diminishes with the legal efficacy of the public filing (Effects of Filing). ${ }^{47}$

Dummy variables in these models also control for the effect of the different origins of property law in each country, distinguishing between those based on English Common Law, Civil Law jurisdictions and the systems applied in former Socialist economies, and, within Civil Law, the three types (French, German and Scandinavian) identified by La Porta et al. (1999). Of interest is that the number of property rights is little affected by legal origin, as only Socialist origin has a statistically significant influence (possibly due to underdevelopment of these systems). On the contrary, the Common versus Civil Law divide or national origin within Civil Law show no

\footnotetext{
46 On the rationale for this principle and its importance, even in Common Law jurisdictions, see Heller (1999), who points out the role it plays in solving the so-called 'anticommons' problems; Merrill and Smith (2000), who argue that it serves to reduce the information costs in transfers of property; and Hansmann and Kraakman (2002), who emphasize the verifiability costs faced by acquirers. These rationales, however, overlook the fact that a system of numerus clausus is needed to control the costs of organizing the consent of those holding potentially affected rights. Information costs and, in particular, verification costs are only part of the costs of consent. The core of real rights, however, is the relationship between both sellers and acquirers with holders of affected rights. A narrow focus on verification leads Hansmann and Kraakman, in particular, to underestimate the likely increase in the costs of consent caused when parties can freely multiply the type and number of individual rights once a verification system has been established.

47 Data come from a survey of national land administration systems prepared by UN-ECE (2000) and answered by high-ranking public officials in land registers or land administration offices. Relevant data is available for 42 of the 43 surveyed jurisdictions: Albania, Alberta, Armenia, Austria, Belarus, Belgium, Bosnia and Herzegovina, British Columbia, Croatia, Cyprus, Czech Republic, Denmark, England and Wales, Finland, France, Germany, Greece, Hungary, Iceland, Ireland, Italy, Latvia, Lithuania, Malta, Manitoba, Moldova, Netherlands, Northern Ireland, Norway, Ontario, Poland, Prince Edward Island, Romania, Russia, Saskatchewan, Scotland, Slovakia, Slovenia, Spain, Sweden, Switzerland and Turkey. The precise definition of the variables is as follows. The dependent variable, Number of Property Rights, is the estimated number of registerable in rem rights that are enforced in each jurisdiction, obtained by combining answers to questions 15- "What forms of land holding are registered (e.g. absolute, provisional, freehold, leasehold, tenancies, shared ownerships, etc.)?"- and question 17_"What rights other than ownership (for example mortgages) must be registered to ensure such right has legal standing?"-in the UN-ECE (2000) survey. The problem of differential 'grain' in these questions was handled by homogenizing the few answers with abnormal detail and assuming a number of 40 for those countries reporting that all land-related documents or any real right can be filed. These adjustments and assumption do not substantially alter the results. The Recording independent variable is a dummy that takes value one for those jurisdictions with recording of deeds. It is calculated from answers to question 13 of the survey, which reads as follows: "Is the registration system based solely on the retention and filing of indexed documents (a register of deeds), or is there a considered examination of the documents and the granting of a 'guaranteed title' to the land by the Registrar?" Similarly, the Effects of Filing variable takes value one for those jurisdictions where the act of filing confers legal status on the rights. It has been computed from answers to question 8 of the survey, which asked if the "[a]ct of registration [including both recordation or registration in our terms] confer legal status on the rights in land". The legal origin of the jurisdictions is directly taken from La Porta et al. (1999).
} 
statistical significance. Similarly, legal origin at the Civil versus Common law level holds no explanatory power for the choice of titling system (columns 5 and 6). However, national origin within Civil Law is significant, as jurisdictions with German roots tend to choose registration, ${ }^{48}$ while those with a French influence show a small but significant proclivity towards recording. These results are fully consistent with the argument given in the Introduction, that titling systems are little related to the legal tradition of each jurisdiction. The main reason for this seems to be that German-style numerus clausus and registration have been adopted in many jurisdictions whose main legal tradition is not German but Common Law (England, for example) or which have been mostly influenced by French law (the case of Spain). ${ }^{49}$

\section{Registration of rights}

Registers of rights contain information not on claims but on the rights themselves. They thus require a previous, complete purge of property rights. Created within the German legal tradition, most of them were developed during the 19th century (Prussia, 1783; Austria, 1794; Spain, 1861; Australia, 1875; Germany, 1900) and are now used in most of the world, including the Australian 'Torrens' variety, which has been introduced in some other Common Law jurisdictions. It is also the system being introduced in most former Socialist and developing countries.

Registers of rights also apply the priority rule. As in deed recording, private contracts gain priority when they are first filed or 'presented' to the register. They are then subject, however, to substantive review by the registrar, in order to detect any potential conflict which might damage other property rights (Part [c] of Figure 1). ${ }^{50}$ Possibilities here differ in the degree to which the law mandates the number and content of property rights and, correspondingly, reduces parties' freedom and registrars' discretion. Where property rights are narrowly defined by law, with stricter application of the numerus clausus principle, collision between rights is less likely and the affected parties are more easily identified by the registrar in order to check that the parties to the contract bring the consents of affected third parties. This is how the German Grundbuch functions. Conversely, when more attributes of property rights are defined by private contract, collision is more likely and it is more cumbersome for the registrar to identify who the affected third parties

\footnotetext{
48 In the sample, all jurisdictions with German-inspired law have registration, causing one-way causation. Certainty is, of course, constrained by the information in the sample, as it remains open to question if the zeroes observed are 'structural zeroes' or, more likely, 'sampling zeroes' (Hosmer and Lemeshow, 2000: 135-40).

49 The possible influence of tract indexation was also tested but shows no statistical significance.

50 In some Northern European jurisdictions, surveying bodies or professionals also perform a similar role with respect to rights having a physical dimension (those relating to boundaries, for example).
} 
are. The Spanish Registro de la Propiedad, for example, works this way. The German solution is simpler but more rigid, while its alternative demands better incentives and qualification from registrars, in accordance with the greater scope and discretion of their work. By simplifying the custodian role of the register, a stricter numerus clausus thus indirectly serves to protect those right holders who might otherwise lose out from the stronger enforcement provided by registration in instances of registration failure.

In any case, rights are registered only when the registrar determines that they do not affect any other property right, or the holders of affected rights have consented. Otherwise, registration is denied and the parties have to restructure their contract or obtain the relevant consents. Information on the register is simplified in parallel with the purge of rights. Rights defined in each new contract are registered together with all surviving rights on the same parcel of land. Extinguished rights are removed or deleted, however, which makes access to the register very simple. Effective identification of each parcel of land is necessary for the system to work, as is the use of a tract index to locate all rights in each parcel. Furthermore, rights are retroactively registered as of the date on which the deeds were first presented. A register of rights can thus be fruitfully seen as a double register: it is both a temporary record of deeds (the 'presentment' book that dates titles), and a definitive register of rights.

This analysis is also consistent with the two main features of registration: the use of a liability rule for solving title disputes, and the enforcement of a more limited set of rights as property - in rem-rights.

First, given that any contradictions are purged ex ante, the register is able to provide 'conclusive,' 'indefeasible' title, meaning that a good faith buyer acquires a property right if the purchase is based on the information provided by the register. ${ }^{51}$ If the seller's right is later shown to be defective, the buyer keeps the property right and the true owner gets a contractual right against the seller and the register. The property right is allocated in these exceptional cases by applying a rule of liability, but this happens only when there has been a failure in the register. The standard property rule, based on right-holders' consent, is applied in normal circumstances.

\footnotetext{
51 Generally, acquirers are not protected in rem by registration against their own sellers. Only third parties are protected, after a further registered transaction, following the principle of 'deferred indefeasibility.' For instance, if seller $S$, who is not the true owner, sells land owned by $O$ to buyer $B$, who partly finances the purchase with a mortgage loan provided by $L$, and the transaction is registered, the land would be kept by $O$, even if often burdened with the mortgage. The buyer would end up only with a contractual obligation against the seller. In principle, many Torrens registration systems have curative effects on the transaction itself and thus protect innocent second parties in the position of $B$ in the above example. For instance, this doctrine of 'immediate indefeasibility' is now firmly established in Australian jurisdictions, even for registration of an instrument that is void for any legal reason (O'Connor, 2003), after initial vacillation by the judiciary (Whalan, 1982: 293-317). In other jurisdictions, exceptions often reduce this curative effect. For instance, cases of fraud were excluded in Cook County (Shick and Plotkin, 1978: 127).
} 
Registration thus interferes with private property much less than is often claimed, ${ }^{52}$ as its intervention focuses on the timing and the completeness of the private purging of rights. Registration is controlled by registrars or judges but ultimate decisions are made by right holders by giving consent. Privacy and recording allow parties more discretion on the timing and heavier reliance on privately produced information. Rights therefore seem to be more the product of private decisions, but this perception is deceptive because even recorded rights retain a higher contractual content, given the survival of conflicting rights in rem. Additional public intervention by the court, also subject to the possibility of allocation failure, is required to transform them into property rights at an in rem level equivalent to that provided by registration.

Registration failure, however, would reduce enforcement of pre-existing rights. For this reason, there must necessarily be few instances of registration failure — otherwise, registration would not survive. Under a rule of liability, registered owners place their property rights in the custody of the register. This is similar to the 'entrusting of possession' in commercial transactions. ${ }^{53}$ In a sense, the register itself is the seller, much as a possessing merchant is. Owners - in general, all registered right holders - also play a monitoring role with respect to the register similar to that played by suppliers with respect to possessing merchants in commercial transactions. Understandably, when registers fail in their custodian role, they collapse under the pressure and desertion of owners.

The structure of records and registers further clarifies the role of adjudication rules in motivating the production of title information. Under registration, only an owner - the seller-is registered at any given moment. Incentives are concentrated to purge rights ex ante (at the time of a prior transaction) and to make sure that the registered owner is the true owner. The opposite happens under recording. Because the true owner and the seller are both potentially on record, the situation is propitious for motivating the production of information at the time of the subsequent conveyance, ex post. Exceptions confirm the argument. Even under registration a rule of property is applied when the acquirer is assumed to know, or could have easily produced, the relevant information. This applies to the universal exclusion of donees and devisees, who remain unprotected but may reasonably be supposed to know the information. Similarly, many laws either

\footnotetext{
52 See, for example, Shick and Plotkin (1978: 20), who focus on the Torrens version, or Piedelièvre (2000: 20), who considers that registration attacks consensual contractual traditions.

53 For commercial transactions, most legal systems reverse the adjudication rule on the basis of the informative value of possession: the buyer keeps the asset provided the seller is a merchant and the buyer lacked knowledge and acted in good faith. See UCC §2-403[2]. Similarly, the German §366 HGB.
} 
directly enforce adverse possessory rights or, indirectly, infer that the buyer acted in bad faith when he knew the seller was not in possession or the public record was wrong. 54

The second key feature of registration is its stricter numerus clausus. In both systems, recording and registration, fewer property rights means that consent is easier to achieve ex ante because it facilitates the production of information as to which rights and right holders are affected and to what extent, and because it reduces bargaining costs. This effect is more valuable under registration, however, because registration aims to avoid any collision of rights ex ante. Registrars have to examine all transactions and parties have to cleanse even minor contradictory rights and title clouds ('fly specks') ex ante. In contrast, under recording, transactions are not necessarily examined ex ante, minor risks are often left alive and insured on a casualty basis, and the lapse of time probably plays a greater role in purging rights through the prescription of conflicting claims. ${ }^{55}$

In addition to the econometric evidence presented in the preceding Section that jurisdictions with registers of rights enforce a lower number of property rights, variety within registers of rights also supports this role of the numerus clausus principle. Registration systems with stricter numerus clausus are able to produce the strongest effects, with transactions concerning property rights being valid irrespective of the validity of the causal obligation, in application of the principle of abstraction or Abstraktionsprinzip that is characteristic of German property law. ${ }^{56}$

\section{Organization and performance of recording and registration}

The previous Sections have identified the basic traits and functional equivalence of titling systems. This knowledge will now be applied to develop some guidelines for the effective organization of two of these systems, recording and registration. Attention will be paid, first, to the role of competition, which is limited by the protection of third parties; second, to the scope for free

\footnotetext{
54 This conjecture on the efficiency of the 'knowledge requirement' is likely to depend on the value of the assets. As emphasized by Baird and Jackson (1984: 312-18), this knowledge exception may produce more nuanced decisions but is costly to apply. To the extent that these costs are largely fixed, we should expect it to be applied more for valuable assets and security interests (also likely to be positively correlated to asset value) than for deciding title claims on standard movables. There is some indication of this in the treatment of commercial transactions, for which knowledge plays no role in most jurisdictions.

55 This makes it unlikely that the observed relation between the number of in rem rights and title systems can be explained as a consequence of registers being able to enforce more cheaply than courts an exogenously-driven numerus clausus policy.

56 On this, see Kohler (1996: 231).
} 
choice, giving parties more or less freedom to switch between systems; and, lastly, to the main drivers of performance in theory and practice.

\section{A. Common organizational principles}

The analysis below will also illuminate the organization of the conveyance industry and its recent evolution, which is characterized by liberalization of private contracting and maintenance of monopoly in recording and registration. In essence, despite the remarkable differences between recording and registration, the conflict of interests amongst parties is the same in both systems. This explains why similar organizational patterns are applied in each contractual step in the two systems. In particular, the private contract between the parties is safeguarded by the parties' free choice of providers. However, independence is required to protect the interests of third parties whose property rights might be damaged by the intended transaction. This also explains why the increasing presence of reputed business firms as parties modifies the market structure of the service industry supporting the private contract but not the public functions behind the second 'contract' by which affected parties express their consent.

\section{Competition as a safeguard of quality in private contracting}

Contracts between parties convey contractual, but not property rights: they oblige parties to the contract but not third parties. These contracts involve substantial information asymmetries, however. Old systems of private conveyance typically mandated the preparation of private contracts by law professionals, on behalf of either one party (British solicitors, US lawyers and conveyancers) or all parties to the private contract (Civil Law notaries). These old systems also claimed to reinforce quality assurance by restricting entry. However, all systems allowed parties to freely choose providers. Under recording, parties choose either lawyers, title agents and insurers (US) or notaries (France). Under registration, they choose among solicitors and conveyancers (England) or notaries (rest of Europe). Most conveyance systems have undergone substantial changes in recent decades. The requirement of mandatory intervention has been relaxed or revoked, barriers to entry lifted, prices liberalized and vertical and horizontal integration has increased. The diminishing role lawyers play in conveyance is shown by the controversy over 'unauthorized practice of law' in the US and the parallel debate in Europe about mandatory notarial intervention in standard transactions. There is an increase in vertical integration of real 
estate development and mediation, title assurance and insurance services, and provision of credit. ${ }^{57}$ Also, freedom to choose among legal professionals is being substituted by freedom to choose the fundamental service. That is, instead of choosing lawyers or notaries, users choose the bank, the real estate agent or the title company and these entities provide the legal services themselves or contract them out. 58

The traditional presence of free choice and these later trends are consistent with our view. Most conveyance systems have remained in line with the contractual reality of the 19th century. Because most parties were individuals, mandatory intervention of law professionals made more sense then (even without judging whether it was necessary or not). Current liberalization trends can thus be seen as an adaptation to the increasing role played as parties by large firms which are able to safeguard the transaction with substantial quasi-rents. Much of what is happening in the industry can therefore be understood as a substitution of parties' quasi-rents for professional quasirents. Some of the parties in standard transactions - banks, title insurers, real estate agents, large developers-have reached positions of impartiality, because they are large and reputed parties contracting standard transactions repeatedly. They can thus engineer and safeguard residential transactions by themselves. ${ }^{59}$ The power of their quality assurance allows these 'impartial' parties to act as 'notaries for the transaction.' Each party to a conveyance contract in Common Law countries is supposed to hire partial assistance to represent his interests. Increasingly, however, US brokers, lenders and title and escrow companies represent more parties to the transactions. In this sense, they are becoming like European notaries. This is happening at the same time as European notaries are becoming increasingly dependent on lenders, who now, for instance, write most mortgage contracts. It seems that there is increasing demand for independent legal advice, but its most efficient providers are non-specialists.

\footnotetext{
57 In most US states, not only are attorneys not involved in most home sales (HUD, 2000: 2), but also insurers have integrated as many functions as they are allowed to and banks are now moving into title insurance and self-insuring titles (Arruñada, 2002). In Britain, solicitors have lost the de facto monopoly they used to enjoy on conveyance and those practicing are increasingly integrated with real estate agents ("Conveyancing-All the Right Moves", Law Gazette, May 26, 2000). French notaries have been main players in real estate mediation for a long time (Suleiman, 1987). Spanish notaries are responding to added competition by increasing group practice and working more closely with banks. Portugal recently reduced the scope of compulsory notarial intervention and made it possible to create specialized private notary offices.

58 This indirect enforcement of reputational safeguards is similar to the indirect selection of financial auditors by investors when buying securities, often triggering similar discussions about professional independence and the scope of services (Arruñada, 1999).

${ }^{59}$ For analyses of this 'asymmetric' relational contracting in other industries, see Arruñada (2000) and Arruñada, Garicano and Vázquez (2001).
} 


\section{Monopoly as a safeguard of independence when third parties are affected}

In sharp contrast to the traditional role of free choice and the current liberalization of conveyance services, decisions on property rights are made by bodies or agents organized on the basis of territorial monopoly. Within our analysis, the explanation is straightforward. Agreeing to exchange contractual rights only obliges the parties, who can then be left to care for themselves. Competition among suppliers will provide quality assurance even in situations of information asymmetry. Property rights, however, oblige everybody. Their creation requires independence from the parties to the transaction, in order to protect everybody's interests. Different institutions exist for this purpose, as we have seen. In essence, privacy and recording do it by delaying the perfection of property rights, while registration forces such perfection to the time of the private contract. However, in all three systems, an independent agent decides which rights will be enforced as property rights and which rights will be merely contractual. Under privacy and recording, this agent is the judge, who eventually decides title matters on the basis of priority as established in the titles and the records office. Under registration, the registrar decides when choosing between registering or requiring specific consents before registration. The incentives for judges, recorders and registrars have the same objective: to make them independent with respect to all the parties. Their impartiality is needed not so much between the parties to the private contract but mainly between them and any third parties, that is, those holding affected property - in remrights.

Given that these potentially affected third parties are not present, that frequently they do not even know the situation and are often diffuse, it is understandable that the parties to the private contract should not be allowed to choose the providers of recording, registration or judging services. Freedom to choose is ineffective in protecting right holders who are not in a position to choose. Take, for instance, the possibility of a lender determining who will decide the priority of his mortgage among many other competing mortgage claims. All kinds of recorders and registers are therefore organized as territorial public monopolies when they produce evidence or directly decide on property rights. Apparently, it is not enough to make the rules of priority mandatory, regardless of who is applying them, probably because they leave substantial scope for interpretation. ${ }^{60}$ Taking extreme precautions regarding independence might be more necessary under registration because of both its powerful effects and its sensitivity to registration failure, which may easily cause the system to collapse (for instance, by judicial decisions that abrogate conclusiveness of registration).

\footnotetext{
60 The argument has focused on legal services and decisions. These systems also keep an archive of cases, records or rights. For these administrative functions, decreasing unit costs may also be generating a situation of natural monopoly. However, by itself this would not preclude free choice of judges, recorders or registrars, who could use a common archive.
} 
Apparent exceptions only reinforce the argument, because multiple recorders or registers are used only in circumstances in which there are no third parties or these third parties remain unprotected ex ante.

First, for registers of financial assets, the best practice seems to consist of having a single clearing agency and depository acting also as a register to eliminate delays between settlement and registration (BIS-IOSCO, 2001: 13), as with the Depository Trust \& Clearing Corporation, DTCC, in the US. 'Indirect holding systems' have two-step registration, however, with a central depository and multiple custodians but, when these custodians also act as first level registers, they are chosen by the issuer of the securities so transactors themselves have no choice. Furthermore, when the issuer switches register, he has to provide the consent of third parties (such as lien holders), in a process supervised by the central register. Additional precautions are taken to avoid conflicts with the register itself. This is mostly done by the drastic measure of preventing the existence of third parties. For this purpose, rights with a potential to cause conflict are simply not enforced as in rem rights (for instance, second liens). Also, the central register is the sole register with legal effects for all securities owned by entities with registration functions.

Second, for Internet domains, there is only one register for each top-level domain (all those ending in, for example, '.com'), but users choose freely among multiple so-called 'registrars' (in fact, recorders). Free choice is possible because the registrars - and the register itself - only allocate the domain on a first-come, first-serve basis, without ex ante control of any potential damage to third parties, mainly holders of intellectual rights in the name. The only ex ante control they perform aims to avoid name repetition, but this is in the interest of the party asking for registration. In fact, the potential to damage third parties' interests when a registration system serves only the interest of the choosing parties is illustrated by the extent of 'cybersquatting,' the registration of prominent names with a view to later selling them back to their trademark owners when said owners wish to start operating online.

The system now provides more protection for third parties ex post, after they complain, by enforcing the Uniform Domain-Name Dispute-Resolution Policy or UDRP (ICANN, 1999) that applicants have to accept ex ante. Its design is consistent with our argument. First, disputes are not decided by the registrars but, according to the UDRP, registrars simply enforce the decisions of the administrative panel selected by the complainant among those 'providers' - that is, arbitratorsapproved by ICANN. Second, there is statistical evidence that free choice of arbitrator by challengers is biasing the results, causing substantial differences in the ratio of successful to unsuccessful challenges across arbitrators (Mueller, 2001). Furthermore, the exception within the exception also ties in with the argument: registers of geographic top-level domains, such as '.de' or '.es,' who exert ex ante control are also monopolies. 
Third, the argument is also consistent with the absence of third party effects of US title plants. Even the exception of the Chicago 1871 fire confirms the rule. True, private abstracts were used in that case for reconstructing the public records, after these were destroyed. However, the private abstracts were produced before the fire, when parties could not have guessed their future public use.

Lastly, the need for those deciding on property rights to be independent from the parties is also shown by the expansion of constraints on private property in connection with zoning and environmental preservation programs. ${ }^{61}$ This expansion can be seen as a consequence of failing to separate parties and decision-makers. In essence, zoning and environmental regulators are at the same time custodians and holders of property rights that allow them to prevent certain uses (for instance, building, filling a wetland, logging a forest). As with any right holder, their consent is required to use the land affected by the regulation. However, as custodians, they also decide if their rights are affected or not by the proposed use or transaction, carrying out a function that is very similar to that of a register. Unsurprisingly, these rights have been expanded beyond initial expectations. The above analysis could be applied to rationalize the system. Leaving aside the controversy on the allocation (or expropriation) of such use rights, a rational system would place the custodian role with independent bodies, be they the legislature, the courts or the register. ${ }^{62}$ This would avoid the risk of an unlimited expansion of rights and would also facilitate the exchange of regulatory consent for compensation.

\section{B. The scope for free choice}

Thus far the analysis has dealt with the different legal systems for enforcing property-in rem - rights as mutually exclusive alternatives. The previous Section has also examined the role of free choice within a given system. The present Section explores the possibilities and difficulties of granting parties freedom of choice between systems, an issue with important practical consequences.

The rationale supporting free choice is, as always, one of improving allocation of resources. Given that legal systems incur different costs of consent and provide diverse levels of enforcement, freedom might allow parties to attain a more efficient outcome, with a better match

\footnotetext{
61 See, for instance, Epstein (1995: 275-305).

62 The importance of this separation can be seen in the fact that expansion has been smaller in areas in which agencies' powers are constrained by law. This is achieved, for instance, by imposing limits on the level of risks or the types of control techniques required by the regulator. The solution resembles the definition of a stricter numerus clausus of property rights, to the extent that this also constrains the discretion of the registrar, as analyzed above.
} 
of demand and supply. The rationale against freedom of choice is also based on standard considerations of external effects. These mainly take the form of damages to rights held by third parties and public goods. The latter are rooted in the fixed cost incurred by the mere existence of each legal and filing system. Some degree of duplication will inevitably have to be suffered by the law, the judiciary and the conveyancing industry if they are to support several systems, and economies of scale will to some extent be lost.

Inescapably, the analysis is bound with a basic ambiguity that has to be solved exogenously. To the extent that freedom might allow owners to hide their property from government, it also intrinsically causes consequences that will vary according to the nature and quality of government. For instance, if owners can opt for privacy, this is likely to make the enforcement of involuntary charges on land, such as land taxes, more difficult. This may be evaluated very differently - as a benefit or as a cost - depending on whether it limits the power of a bad or a good government, respectively.

Parties' freedom can be granted in two ways. First, freedom to choose between privacy and publicity and, within publicity, freedom to chose between different forms of publicity. Second, at least theoretically, the law could allow both choices to be made only once for each parcel or right, or once for each transaction. Fortunately, a comprehensive examination of all theoretical possibilities is unnecessary, as it would involve repetition and many of them are empirically irrelevant. ${ }^{63}$ This seems applicable, in particular, to freedom to choose a permanent legal system (be it privacy, recording or registration) for each parcel. This could theoretically be implemented by having this choice entered into some sort of public cadastre. One could imagine a recorded deed or a registration entry stating 'Parcel $X$ will be traded under a regime of privacy', or words to that effect. The permanent character of such entries would be doubtful, however. First, it would introduce a costly rigidity, as nothing guarantees that a choice that is optimal today remains optimal in the future. For instance, preferences would vary with financial need: many owners may well prefer privacy unless they want to use their land as collateral, given the advantages that publicity systems are believed to provide for this latter purpose. These mismatches would generate demand for switching. Second, the operation of such a system would require maintaining a kind of cadastre in which all parcels and their chosen legal regime were identified. As a consequence, the system would remain open to the risks of political opportunism.

Only two sets of choices will therefore be discussed: freedom to switch between privacy and publicity, and freedom to switch between recording and registration.

63 Given that most experiences of free choice have been structured as transitions into registration, they provide limited information for evaluating a hypothetical system purposely designed to provide this freedom. 


\section{Freedom to switch between privacy and publicity}

Unrestrained freedom to switch between privacy and publicity would cause serious damage to other right holders, under both registration and recording. The powerful effects of registration make the act of registering or deregistering a parcel of land potentially damaging for rights held on that parcel and neighboring ones. For example, rights kept private may be destroyed in their in rem nature by registration or by renewing a 'broken tract' on the same parcel, or may be substantially damaged by registering the boundaries of a neighboring parcel incorrectly. Supporting evidence is provided on this by the additional precautions that most registration systems take with respect to initial registration and their common prohibition of deregistration. ${ }^{64}$ When allowed, deregistration of a land parcel requires an 'inverse purging' procedure, in which all right holders in rem can object. 65

If allowed, opportunistic filing and de-filing of deeds would pose similarly serious hazards through the operation of the priority-in-recording rule. Under recording, where there is no active registrar, this risk is partly offset only by putting more strict requirements on buyers for them to be considered in good faith and/or to be more diligent in producing information on adverse possession.

Under both systems, however, a sort of optional privacy is often allowed indirectly, to the extent that the law relies on possession as evidence in conflicts on property rights. ${ }^{66}$ When, to be considered in good faith, acquirers are required to diligently inspect the land regarding adverse possession, right holders can keep possessory rights unrecorded or unregistered. In such cases, all other rights remain on file and are therefore unaffected by the choice of keeping the new right private. In such cases, removal of these rights from the public record or register is in fact allowed, but in a direction that cannot damage property rights already held by third parties. ${ }^{67}$

\footnotetext{
64 It seems that registers have most often resisted de-registration. See, for the United States, Shick and Plotkin (1978: 95 and 139) and note 65 below. In England, the reform of 1925 definitely eliminated the possibility for transfers out of the register that was momentarily opened by the sentence in Capital \& Counties Bank Ltd. v. Rhodes (Sparkes, 1999: 79). In most other jurisdictions it has always been impossible.

65 For example, Massachusetts made it possible to voluntarily de-register more types of land from the Torrens register as from February 11, 2001. Consistent with our argument, before de-registration is approved, an examiner of title is appointed to ascertain if mortgagees or lessees are affected and to give them notice, thus providing an opportunity for them to object (MCA, 2001).

66 For practical purposes, it hardly matters if registration is legally mandatory, as in England, or not, as in Spain, because this distinction is much less important than the legal treatment of possessory rights. It is often understood that, under voluntary registration, parties are allowed to create 'property rights' among themselves without registering. However, to the extent that these rights produce in rem effects only among the parties, without obliging third parties, they are better considered as contractual rights. Conversely, when the law is willing to enforce 'overriding interests' and similar possessory rights in rem, as in England and to a lesser extent Spain, property rights that oblige all people can in fact be created without a public filing.

67 This objective to protect third parties is also shown by the fact that registration systems often grant purchasers and foreclosing mortgagees a right to compel registration.
} 


\section{Freedom to switch between recording and registration}

Given the different levels of security provided by recording and registration, granting owners freedom to choose between the two of them could be beneficial. Theoretical models have shown that, under sensible assumptions, the more defective the title and the more valuable the land, the more landowners would be likely to opt for registration. ${ }^{68}$ This also finds some empirical support in the choices effectively made in jurisdictions with both systems in the USA and in the registration of possessory rights in Spain. ${ }^{69}$ The best known experience is that of Cook County, where a record of deeds and a Torrens register of rights were functioning simultaneously until 1997.70

A complementary rationale for granting freedom between recording and registration is that this freedom could provide some degree of competition between both systems. This however, would be unlikely to function properly. First, given the conclusive nature of registered title, the more freedom parties have, the more serious the adverse selection problem suffered by the register, increasing its operating costs and losses for its insurance fund. ${ }^{71}$ Price flexibility may then become crucial, but it is hard to achieve in a public bureaucracy. ${ }^{72}$ Second, competition would take place between a public agency (registration) and the private conveyance and assurance industries, with the latter being at the same time both an user and a competitor of the filing office. This would be likely to cause conflict if registration reduces the potential market for private assurance. Especially if the register is a standard public agency (registrars without residual rights),

\footnotetext{
68 See, respectively, Miceli et al. (2002), and Arruñada and Garoupa (2002).

69 For the US, Shick and Plotkin (1978). For Spain, the comment is based on data from the Land Register over the period 19001944, which show that land newly registered under possessory rights was of lower value than that newly registered under ownership.

70 The empirical results obtained by Miceli et al. (2002) with Cook County data show that right-holders self-selected into one of the two systems and that registered land had a higher price than would have been expected had it been recorded, all other things being equal. Prices of recorded land, however, were lower than would have been expected had it been registered. The later result is all the more striking considering that two years after the Miceli et al. sample, 95 percent of all Torrens transactions in Cook County were also buying title insurance, as reported by McCormack (1992: 108), with the obvious duplication that this would involve. This awkward result could be consistent with rational self-selection, however, if recorded land faced higher switching costs, which is consistent with the additional burdens and delays of initial registration, including a judicial proceeding (see Shick and Plotkin, 1978: 128-29, 135, 138, note a). In addition, if new registrations in 1986-87 were as insignificant as ten years earlier, and deregistration continued to be forbidden (Shick and Plotkin, 1978: 134-35, 139, 141), filings in the sample could be mostly within the same system and the choice of system was in fact heavily constrained. Under such circumstances, it might have been advisable to take the selection process as exogenous, using a 'naïve' model of land prices in the two systems. The significance of the variable representing locations with higher concentration of Torrens registration in the selection model could then be explained by the historical account in Shick and Plotkin (1978), who tell how, within Cook County, almost all land in some areas was either recorded or registered.

71 Shick and Plotkin point out the tendency of owners with doubtful titles to apply for registration in the three main Torrens registers they analyze, those of the Twin Cities, Massachusetts and Cook County (1978: 93-95, 118 and 141).

72 For instance, pricing policy did not seem to consider the substantial difference in the costs of running each system in Cook County, according to Shick and Plotkin (1978: 136), which could explain the deficit of its Torrens operation (p. 138). Particularly striking was the registrar's fee for initial registration of only $\$ 30$ (p. 135).
} 
competition in the political market might lead to a situation in which the register is more or less captured or degraded by the industry. This argument may be relevant to explain the suppression of registers of rights in some US jurisdictions or, more clearly, their transformation into registers of deeds in some South American countries.

Finally, two modest but common applications of choice are where procedures are introduced for fully purging a title within recording and, conversely, where some optional elements of recording are introduced into a registration system. First, registration effects are introduced into a recording system when a low-cost judicial purge is organized, making it possible to get conclusive title when needed. Second, registration of possessory rights may produce legal effects intermediate to those of recording and registration, including priority and most often an expectation of ownership after a certain period of time. ${ }^{73}$ Registers of rights could thus be designed to function with three levels of freedom: registered rights, registered possessory rights and unregistered possessory rights. For unregistered land, the Spanish system offered these three options between 1861 and 1944.

\section{Performance: promised and delivered}

This Section compares the performance of recording and registration in terms of their two basic elements: enforcement benefits and consent costs. Without aiming to give a comprehensive account of the issues involved, ${ }^{74}$ the analysis clarifies two of the main theoretical arguments in the old controversy about these systems - the superiority of recording with respect to costs and its inferiority with respect to effectiveness. ${ }^{75}$ It thus shows which factors can substantially modify their theoretical comparative advantage in practice. Before proceeding, it is necessary to clarify

\footnotetext{
73 Registration of possessory titles, which essentially applies the general property concept of using possession as 'the root' of title (Epstein, 1979), usually make up for the lack of a full purge of rights. These rights do not become absolute until the expiration of a limitations period. It has been seemingly used in most jurisdictions. For example, the English Land Register registers possessory titles to freehold and leasehold estates as well as qualified titles when it is not fully satisfied with the evidence of ownership (Sarton, 2000: 32-33) and also 'cautions against first registration' by claimants on unregistered land (Silverman, 2001: 462). All of them are maintained in the Land Registration Act of 2002. Similarly, in Spain, registration of possessory rights was much in demand from 1861 to 1944, when a legal reform promoted by notaries (monopolistic conveyancers) made it impossible and, at the same time, granted overriding status to unregistered possession. In Minnesota, since 1982 possessory rights can be registered and, if unchallenged, become conclusive after five years.

74 Arruñada and Garoupa (2002) provide a formal comparison that considers the socially optimal level of assurance. It shows that, in both recording and registration, current owners tend to overspend in assurance services, in a version of the familiar problem of excessive level of care when private benefits are higher than social benefits (see, for example, Shavell [1997]).

75 See, for instance, the opinions along these lines of Cribbet (1975: 318), Janczyk (1977), Baird and Jackson (1984: 305) and Bostick (1987). Other authors, considering the US experience with Torrens registration, conclude that registration is costlier and less effective (Shick and Plotkin, 1978). The issues have been controversial almost everywhere. See on this, for Australia, Whalan (1982: 3-12); England, Anderson (1992); France, Picod (1999: 535); Spain, Oliver (1892); and, for the US controversy of the 1930s, Powell (1938) and McDougal and Brabner-Smith (1939).
} 
that, in line with the previous analysis, when comparing registration with public recording, the latter is understood as including the services of examination and assurance of title quality provided by lawyers, title agents, title insurers, notaries and the like. ${ }^{76}$

\section{Is recording really less costly?}

Even when defined in this way, recording probably still enjoys an advantage in terms of lower costs. This stems essentially from incentives in both the demand and the supply sides of the industry: title examination and purging are voluntary, and most supporting services are provided on the basis of private enterprise. However, registration requires ex ante purging organized by a public authority.

On the demand side, the main benefit of having an optional purge is that any defects not worth purging can be insured on a casualty basis either by the parties themselves or by a third party insurer. Under registration, the requirement to remove these minor defects may cause holdouts with substantial bargaining costs. ${ }^{77}$ These occurrences are less frequent with a stricter numerus clausus, as analyzed above, but a stricter numerus clausus may be costly in terms of flexibility. Also, it is often pointed out that recording enjoys the advantage of private incentives in the supply of title assurance and insurance services. ${ }^{78}$ Under recording, titles are examined and consents are gathered by business firms or professionals paid with a residual profit. Assuming competition, costs will tend to be minimized and efficiency achieved, including rapid innovation and adaptation to changes in technology and demand.

These cost advantages may be illusory, however, given the incentives of both users and suppliers. Voluntary title assurance may incur costs similar if not higher than those of public registration because of duplicated efforts and lost economies of scope. Private organization of support services also suffers, as many of such services are natural monopolies and are heavily regulated.

\footnotetext{
76 Both registration and recording can be complemented with different degrees of casualty-based title insurance. This complementarity is being shown by the introduction of title insurance in jurisdictions with registration, analyzed in Arruñada (2002). The next stage in the evolution of these systems could well consist of registration plus no-fault insurance for the whole conveyance process, to be provided by private title insurers offering conveyance services or at least enforcing the (often theoretical) strict liability of conveyancers, notaries and registers.

77 This can be seen as an example of the 'anticommons' problem analyzed by Heller (1998), Heller and Eisenberg (1998) and Buchanan and Yoon (2000).

78 As a major property law textbook asserts, "title registration puts title assurance in the hands of the government whereas the recording system puts title assurance in private hands using the public records" (Dukeminier and Krier, 1998: 721). This might allow recording to produce better information on title quality, supposedly overcoming its information difficulties, as "the private company with a profit motive will do a better job of identifying flaws up front as compared to the government which, presumably, is only interested in balancing the budget" (Miceli and Sirmans, 1995: 86).
} 
Recording endures a substantial degree of duplication even when a mature title assurance sector develops. First, title plants have to file information on all transactions and relevant facts, not only on those rights being transacted or examined. Consequently, there is less advantage in being able to choose between ex ante or ex post purging. Second, title plants serve only companies' internal administrative functions, as they have no legal effect. This causes that the whole chain of title is examined for each transaction. ${ }^{79}$ Third, a double duplication of costs takes place in the US system. Private title plants duplicate the information of the public registers. In addition, different title plants hold duplicate information, given that in many areas there is more than one title plant. Some duplication can be avoided with better-organized recording offices - mainly, by using a tract index. General automation may also facilitate gathering information from public records and reduce the extent and cost of archive duplication in the near future. It will hardly avoid, however, the need for filtering this information or contain duplication in repeated examination of old titles.

Potential economies of scope in information production and purging of rights and of register information are also hard to reach under recording. Information on the quality of titles is underutilized and has to be produced repeatedly. This is also due to the voluntary nature of purging, as in some cases title defects are not removed after being identified by the title report. Furthermore, even when defects are removed, the information on the public records is not simplified accordingly. The public register accumulates information on all kinds of rights, defective and clean, dead and alive. ${ }^{80}$ This mix of rights increases the cost of future title searches. Potential savings will be incomplete and will depend on hiring the same expert. Private title plants can simplify their information, but they still face similar problems. ${ }^{81}$

Secondly, with respect to suppliers' incentives, the two main title assurance industries developed under recording of deeds have been heavily regulated. Both in France and the US they have administered pricing, entry barriers and comprehensive rules on products and processes, partly as an end result of incidents of fraud and bankruptcy. ${ }^{82}$ In particular, as title plants enjoy

\footnotetext{
${ }^{79}$ Marketable title statutes limiting the time depth of required title searches reduce this cost but may also threaten the security of property rights.

80 This perverse effect may be reduced if the legal system or the interest in inducing demand drives notaries or lawyers to purge all titles before recording the deeds. This seems to have been the case in Ontario, where the conversion of deed recording (there called 'Registry' system) into a register of rights ('Land Titles') is claimed to have been made possible by the cumulative work of lawyers in examining and purging titles (Troister and Waters, 1996). Observe, however, that the recording system then loses the previously mentioned advantage of 'insuring over' instead of curing minor title clouds.

81 Relying on their own old title reports is risky because the law may have changed since the previous examination (Johnson, 1966: 401). In fact, even if a new insurer is retained in a later transaction, it will frequently examine the full chain of title again. These problems are shown by the diversity of practices and proposals regarding reliance on prior examinations (McCormack, 1992: 126) and reissue discounts (Boackle, 1997).

82 See Suleiman (1987) for French notaries, and Lipshutz (1994), Nyce and Boyer (1998), Burke (2000, chapters 14 and 15) and Palomar (2000, chapters 15 and 18) for US title insurance.
} 
decreasing unit costs, ${ }^{83}$ suppliers are good candidates for becoming natural monopolies. Understandably, their behavior has been repeatedly scrutinized and sanctioned by competition authorities. ${ }^{84}$

Moreover, registration systems display a variety of incentive structures and results in terms of, at least apparent, productivity. Some of the most appalling results were produced by registers with standard fixed-salary bureaucracies (Cook County, Puerto Rico, England before 1990). More professional, judicial-style bureaucracies, as in Germany or Scandinavia, seem to produce different outcomes, however, especially when each registrar is compensated with the profits of his or her office. ${ }^{85}$ A corporate version of this Ancient Regime predecessor of private franchise management has also been used to set up registration in some developing countries. ${ }^{86}$ This possibility shows that the conversion of private title plants into registers of rights 87 is not as strange as it might appear.

\section{Is registration really more effective?}

It is also often believed that registration is more costly but provides more security for property rights, for several reasons. Mainly, registration makes it possible to use a rule of liability, instead of a rule of property, fully protecting good faith acquirers. In principle, the protection granted by recording is intrinsically inferior in that it is largely contractual in nature so does not take advantage of all the enforcement benefits of property rights. Moreover, as argued above, the protection given to registered right holders by a surviving registration system cannot be detrimental to current right holders. As pointed out by Baird and Jackson, "[i]n a world where information is not perfect, we can protect a later owner's interest fully, or we can protect the

\footnotetext{
83 The costs of building and maintaining title plants are fixed (Lipshutz, 1994: 28) and account for up to half the total costs of title insurance companies (Plotkin, cited by Villani and Simonson, 1982: 274, n. 6).

84 See FDC (1999) for references to two acquisitions which led to consolidation of title plants in several markets. Divestures were required by antitrust authorities later.

85 In this case, a government department manages the relation with a professional network of civil servants. The department regulates entry, processes and prices. Each civil servant then manages an office, recruiting its employees, who are not civil servants and may also be paid with a share of the residual. (A similar hybrid organization was analyzed in Arruñada [1996]). This old arrangement is similar to the one being applied in modern public services reforms. These, however, often have grander plans but weaker incentives, as shown by the paradigmatic 'internal market' and 'fund-holding' doctors invented by the 1989 reform of the British NHS.

86 For example, in Moldova and St. Lucia (http://www.stewart.com, accessed June 2, 2001). A move in this direction was the transformation in 1990 of the English Land Register into a semi-privatized executive agency, with huge productivity improvements (Sparkes, 1999: 18). A similar transformation took place in The Netherlands in 1994 (de Jong, 1998). However, franchised solutions certainly suffer the typical problems of regulated monopolies (Williamson, 1976; Laffont and Tirole, 1993, Levy and Spiller, 1994).

87 As defended by Janczyk (1977: 226-27).
} 
earlier owner's interest fully. But we cannot do both" (1984, p. 300). The assertion is accurate but the assumption is crucial: registration is designed to produce perfect information and thus protect both the earlier and the later owner. ${ }^{88}$ If it fails to protect owners on a significant number of occasions its chances of survival are very limited. ${ }^{89}$

These requirements are not guaranteed when creating a new register, however. They are even at risk in functioning registers, because of several systematic but not universal inadequacies. Established registers mainly fail to fulfill the promises of registration by being slow and incomplete. Oddly, they also fail by being too effective.

Slowness means that a long time is needed to get registration. Meantime, private deeds are given priority conditional to final registration, so that, during the 'registration gap,' the register functions as a record of deeds. ${ }^{90}$ The registers of Cook County, England and Puerto Rico saw chronic episodes of registration delay, which resulted in very different outcomes - closure, successful reform and title insurance, respectively. The lesson is that registration can only function properly with sound incentives. Governments are not always prepared to provide or keep them, however.

Incompleteness of registration is driven by both legal and judicial decisions which lead to enforcement as property — in rem —rights of interests which are not registered. ${ }^{91}$ This causes some difficulty for those 'overriding interests' which are easily observable (such as possessory rights), but poses a more serious problem for abstract overriding interests (such as tacit liens produced by operation of the law, held by employees and governments, for instance). Any proposed solution to the problem comes up against not only legislative barriers but also conveyancers' and judicial opposition. Conveyancers often seek to protect their market: the weaker the effects of registration, the greater the demand for private title assurance services. Registration of rights also constrains the monopoly of the courts in deciding cases. If registration decisions are conclusive, courts cannot allocate property rights but only contractual rights, and this may limit their freedom to decide on

\footnotetext{
88 Referring to recording but in a similar vein, Epstein (1987: 18) asserts, "[t]he basic system of recordation is best understood as an institutional response to the structural weaknesses in any common-law resolution of the ostensible ownership problem. Common-law solutions attempt to reduce the total loss by assigning it to one party or another. Institutional responses seek to eliminate the loss by a more comprehensive system of social control" (Epstein, 1987: 18, emphases in the original).

${ }^{89}$ Some formal models differ from this when assuming that recording (plus title insurance) and registration are on an equal footing with the incidence of claims - that is, the same level of surviving defects. For example, Miceli and Sirmans (1995), Miceli, Sirmans and Turnbull (1998), and Miceli, Sirmans and Turnbull (2000). In contrast, Miceli, Sirmans and Kieyah (2001), and Arruñada and Garoupa (2002) assume unequal incidence.

90 The registration of 'caveats,' giving notice of uncertain outstanding interests, has a similar effect (McCormack, 1992: 91), but only on those titles affected.

91 Rose summarizes this tendency graphically when she points out the repeated failed attempts at clarifying property law: "legislatures pass new versions of crystalline record systems — only to be overruled later, when courts once again reinstate mud in a different form" (1988: 580). For history and references, see mainly pp. 585-90.
} 
the basis on fairness. ${ }^{92}$ It is understandable that courts tend to defend their monopoly when the registers are not part of the court system, which is a common occurrence because malfunctioning of the courts is a main motivation for creating a land register. Even when registers do not err often, judges are only too keen to deny the conclusiveness of registration, thus debasing the system. These problems have been suffered by many registers, not only in the United States. This is perhaps why one of the most complete registers, the German Grundbuch, has traditionally been under the responsibility of judges. ${ }^{93}$

Finally, governments find it useful to use effective registers as gatekeepers for all kinds of public obligations. ${ }^{94}$ This has always been done by explicitly defining a certain obligation as a property burden. Land taxation is an old example for privacy, recording and registration. ${ }^{95}$ Public use regulation is a more recent case. It is tempting for governments to require even minor obligations to be fulfilled before a right can be registered, implicitly granting them in rem status. ${ }^{96}$ Taken to extremes, this may lead users to avoid the register. Furthermore, when the obligations are generally perceived as inefficient, there will be a temptation to dilute enforcement instead of changing the law. While it would be unfair to make an effective register responsible for failures in the political system, it is clear that political constraints cannot be forgotten in its design and administration.

\section{Concluding remarks}

Relying on a trade-off between enforcement benefits and the costs of gathering right holders' consent, this article explains three distinctive features of property law institutions. First, the enforcement of property—in rem — rights by right holders' consent. Second, the use of a

\footnotetext{
92 As analyzed by Rose (1988, especially pp. 584-85 and 597-601).

93 Something similar can be said about the land court of Massachusetts that is responsible for administering its Torrens register: "Unlike other jurisdictions, the Massachusetts courts have not carved out any additional exceptions to the legal conclusiveness of the certificate of title" (Shick and Plotkin, 1978: 106). Furthermore, the register is relatively complete with, for instance, mandatory registration of boundaries (p. 118).

94 See Kraakman (1986) for a theory of legal gatekeeping.

95 Policy reformers in the $18^{\text {th }}$ and $19^{\text {th }}$ centuries were conscious of this issue: their original decisions to place the registers within the realm of the Ministry of Finance (France) or the Ministry of Justice (Germany, Spain) were related to their primary goals of making them an instrument for tax collection and private contracting, respectively.

96 The tendency to make information on registers freely available to the public, and not only to those with a legitimate interest or those so authorized by right holders, as was customary in registration systems, may have similar effects, aggravated by the power of new technologies to bring together data from disparate sources.
} 
'publicity' rule instead of a 'contract' rule when setting the priority of property rights, which makes enforcement by consent viable. Third, the use of the rule of 'liability' instead of the rule of 'property' under registration of rights, which reduces transaction costs and enhances enforcement further.

The analysis has a positive orientation as it focuses on explaining how these institutions work. However, it also provides a basis for policy recommendations in the design and administration of land recording and registration systems. This is more certain with respect to the basic organizational patterns common to publicity systems, which have been determined and, to some extent, tested in Part III. Nevertheless, the analysis also has potential for illuminating the choice between privacy and publicity, as well as, within publicity, between recording and registration.

These are major questions for institutional design in economic development. Following the advice and often with support from international aid agencies, many developing countries are opting for publicity and, within publicity, for registration. Many of these costly registration efforts have failed, however, ${ }^{97}$ and a more thoughtful approach may be advisable. The above analysis did not aim to reach a conclusion in terms of comparative efficiency but it makes clear that efficiency depends on environmental fitness and organization. Policy decisions should therefore consider the specifics of each case instead of applying a universal recipe.

As argued in Section I.C, privacy should be preferred to publicity when the expected number of transactions is low and the risk of political opportunism is high. The presence of both of these circumstances casts doubt on the current drive to construct complete registration systems in countries with low degrees of economic and political development. First, the gains from trade in land are probably still too constrained by technology and lack of profitable investment opportunities in many areas. Titling by publicity fits well into Demsetz's (1967) theory: being costly, improved delineation of rights is worthwhile only when benefits are greater than costs. ${ }^{98}$ And benefits in this case depend crucially on effective demand for secured credit and transactions with strangers, both of which are often uncertain, due non-legal factors. Second, potential losses from publicity may well also be higher than expected, given the substantial risk of excessive taxation. Certainly, titling can make uncertain possessory rights more secure, generating positive external effects, but it is unclear which kind of titling or political effort may achieve that result more efficiently. At first sight, historical evidence is broadly consistent with the argument. For a long time, European societies hesitated about introducing publicity. ${ }^{99}$ When they finally arranged

\footnotetext{
97 See, for example, Atwood (1990), Place and Migot-Adholla (1993, 1998), and Larson, Palaskas and Tyler (1999).

98 Costs functions of alternative systems are discussed in Arruñada and Garoupa (2002).

99 The now common conflict between customary and new land law institutions also finds a parallel in European history, where publicity was generally defended by cities and opposed by the nobility. These positions may be explained as a conflict of
} 
functioning systems, in the 19th century, they seemingly did it for the purpose of making secured credit possible and, even then, most governments registered land very slowly over a period of more than a century. The mixed results found in empirical analyses of current projects are therefore unsurprising.

With respect to the choice of publicity system, the article focuses on recording and registration in a steady state. This perspective should help in adapting existing systems to current conditions, as in facilitating vertical integration in the provision of conveyance services. It should also help to avoid the risks posed to these systems, probably more so to registration, by conveyancers' rentseeking, judicial opposition and poor design of providers' incentives. To assist in the choice of a new system, other factors should be considered. In addition to those mentioned in the article, such as the incentives and scope needed for registration to function properly, careful attention should be paid to differences in the cost of putting a new system in place, such as pre-existing property rights and titling schemes.

\section{References}

Aghion, Philippe, and Benjamin E. Hermalin. 1990. "Legal Restrictions on Private Contracts Can Enhance Efficiency," 6 Journal of Law, Economics, and Organization 381-409.

Alston, Lee J. 1984. "Farm Foreclosure Moratorium Legislation: A Lesson from the Past," 74 American Economic Review 445-57.

Alston, Lee J., Gary D. Libecap, and Bernardo Mueller. 1999. Titles, Conflict and Land Use: The Development of Property Rights and Land Reform on the Brazilian Frontier. Ann Arbor: University of Michigan Press.

Alston, Lee J., Gary D. Libecap, and Robert Schneider. 1996. “The Determinants and Impact of Property Rights: Land Title on the Brazilian Frontier," 12 Journal of Law, Economics and Organization 25-61.

Anderson, J. Stuart. 1992. Lawyers and the Making of English Land Law, 1832-1940. Oxford and New York: Clarendon Press and Oxford University Press.

Anderson, Terry L., and Dean Lueck. 1992. "Land Tenure and Agricultural Productivity on Indian Reservations," 35 Journal of Law and Economics 427-54.

Anderson, Terry L., and Peter J. Hill. 2002. "Cowboys and Contracts," 31 Journal of Legal Studies (issue 2, Pt 2) S489-S514.

jurisdictions. Of interest is that the nobles and the Church had developed their own manorial registers and levied taxes on land. Understandably, they resisted reforms through which the State was legitimating and potentially taxing property directly. Something similar may be happening now with reforms in some developing countries. 
Arruñada, Benito, and Nuno Garoupa. 2002. "The Choice of Titling System in Land," Universitat Pompeu Fabra, Economics and Business Working Paper Series, 607

(http://www.econ.upf.es/cgi-bin/onepaper?607, accessed December 13, 2002).

Arruñada, Benito, Luis Garicano, and Luis Vázquez. 2001. "Contractual Allocation of Decision Rights and Incentives: The Case of Automobile Distribution," 17 Journal of Law, Economics, and Organization 256-83.

Arruñada, Benito. 1996. "The Economics of Notaries," 3 European Journal of Law and Economics 5-37.

Arruñada, Benito. 1999. "The Provision of Non-Audit Services by Auditors: Let the Market Evolve and Decide," 19 International Review of Law and Economics 513-31.

Arruñada, Benito. 2000. “The Quasi-Judicial Role of Large Retailers: An Efficiency Hypothesis of their Relation with Suppliers," 92 Revue d'Economie Industrielle 277-96.

Arruñada, Benito. 2001. “A Global Perspective on Title Insurance,” 16 Housing Finance International 3-11.

Arruñada, Benito. 2002. "A Transaction-Cost View of Title Insurance and its Role in Different Legal Systems," 27 The Geneva Papers of Risk and Insurance 582-601.

Atwood, David A. 1990. "Land Registration in Africa: The Impact on Agricultural Production," 18 World Development 659-71.

Ayres, Ian, and Eric Talley. 1995a. "Solomonic Bargaining: Dividing A Legal Entitlement to Facilitate Coasean Trade," 104 Yale Law Journal 1027-117.

Ayres, Ian, and Eric Talley. 1995b. "Distinguishing Between Consensual and Nonconsensual Advantages of Liability Rules," 105 Yale Law Journal 235-53.

Ayres, Ian, and Jack M. Balkin. 1996. "Legal Entitlements as Auctions: Property Rules, Liability Rules, and Beyond," 106 Yale Law Journal 703-50.

Ayres, Ian, and Paul M. Goldbart. 2001. "A Critique of 'Tangibility' as the Basis for Property Rules," Yale Law \& Economics Research Paper, 251 (http://papers.ssrn.com/sol3/delivery.cfm/SSRN_ID262185_code010309520.pdf?abstractid= 262185, accessed July 12, 2002).

Baird, Douglas G., and Thomas H. Jackson. 1984. "Information, Uncertainty, and the Transfer of Property," 13 Journal of Legal Studies 299-320.

Baker, Matthew, Thomas. J. Miceli, C. F. Sirmans, and Geoffrey K.Turnbull. 2002. "Optimal Title Search," 31 Journal of Legal Studies 139-58.

Barzel, Yoram. 1997. Economic Analysis of Property Rights, 2nd ed. (1st ed., 1989). Cambridge and New York: Cambridge University Press.

Besley, Timothy. 1995. "Property Rights and Investment Incentives: Theory and Evidence from Ghana," 103 Journal of Political Economy 903-37.

BIS-IOSCO, Bank for International Settlements-International Organization of Securities Commissions. 2001. Recommendations for Securities Settlement Systems, Consultative Report. Basel: BIS (http://www.bis.org/publ/cpss42.pdf, accessed November 9, 2001).

Blackstone, William (1765-1769). Commentaries on the Laws of England, excerpt reproduced in S. F. Kurtz and H. Hovenkamp, Cases and Materials on American Property Law. St. Paul: West, 1988, 1108-09. 
Boackle, Kenneth F. 1997. Real Estate Closing Deskbook: A Lawyer's Reference Guide \& StateBy-State Summary. Chicago: General Practice, Solo and Small Firm Section, American Bar Association.

Bostick, C. Dent. 1987. "Land Title Registration: An English Solution to an American Problem," 63 Indiana Law Journal 55-111.

Braverman, Avishay, Karen M. Brooks, and Csaba Csaki, eds. 1993. The Agricultural Transition in Central and Eastern Europe and the Former U.S.S.R. Washington, D.C: The World Bank.

Buchanan, James M., and Yong J. Yoon. 2000. "Symmetric Tragedies: Commons and Anticommons," 43 Journal of Law and Economics 1-13.

Burke, D. Barlow. 2000. Law of Title Insurance, 3rd. ed. (1st ed., 1986). New York: Aspen Law and Business.

Cabrillac, Michel, and Christian Mouly. 1997. Droit des sûretés, 4th ed. Paris: LITEC, Libraire de la Cour de cassation.

Calabresi, Guido, and A. Douglas Melamed. 1972. "Property Rules, Liability Rules, and Inalienability: One View of the Cathedral," 85 Harvard Law Review 1089-128.

Coase, Ronald H. 1960. "The Problem of Social Cost," 3 Journal of Law and Economics 1-44.

Cooter, Robert D. 1985. "Unity in Tort, Contract, and Property: The Model of Precaution," 73 California Law Review 1-51.

Cribbet, John E. 1975. Principles of the Law of Property. Minneola: The Foundation Press.

Cross, Harry M. 1957. “The Record 'Chain of Title' Hypocrisy,” 57 Columbia Law Review 787800.

Davis, Lance E., and Douglas C. North. 1971. Institutional Change and American Economic Growth. Cambridge: Cambridge University Press.

de Jong, Jitske. 1998. “Access to Geo-information in the Netherlands: A Policy Review,” in J. Zevenbergen, Free Accessibility of Geo-Information in the Netherlands, the United States and the European Community. Delft: Delft University Press.

de Soto, Hernando. 2000. The Mystery of Capital: Why Capitalism Triumphs in the West and Fails Everywhere Else. New York: Basic Books.

Demsetz, Harold. 1967. "Toward a Theory of Property Rights," 57 American Economic Review 347-59.

Diamond, Arthur S. 1975. The Evolution of Law and Order. Westport: Greenwood Press. (First ed. London: Watts, 1951).

Dukeminier, Jesse, and James E. Krier. 1998. Property, 4th ed. New York: Aspen Law and Business.

Ellickson, Robert C, and Charles D. Thorland. 1995. "Ancient Land Law: Mesopotamia, Egypt, Israel," 71 Chicago-Kent Law Review 321-411.

Ellickson, Robert C. 1993. "Property in Land," 102 Yale Law Journal 1315-400.

Epstein, Richard A. 1979. "Possession as the Root of Title," 13 Georgia Law Review 1221-43.

Epstein, Richard A. 1987. "Inducement of Breach of Contract as a Problem of Ostensible Ownership," 16 Journal of Legal Studies 1-41. 
Epstein, Richard A. 1995. Simple Rules for A Complex World. Cambridge: Harvard University Press.

Espinoza Soriano, Waldemar. 1997. Los incas: Economía, sociedad y estado en la era del Tahuantinsuyo, 3rd ed. Lima: Amaru Editores.

FDC, Federal Trade Commission. 1999. Annual Report to Congress. Fiscal Year 1998. Washington DC: Department of Justice Antitrust Division (http://www.ftc.gov/bc/hsr/98annrpt/hsr98annual.htm, accessed June 2, 2001).

Finley, Moses I. 1952. Studies in Land and Credit in Ancient Athens, 500-200 B.C.: The HorosInscriptions. New Brunswick: Rutgers University Press.

Finley, Moses I. 1953. "Land, Debt and the Man of Property in Classical Athens," in M. I. Finley, Economy and Society in Ancient Greece. London: Chatto \& Windus. 1981: 62-76. (Originally published in 68 Political Science Quarterly 1953: 249-68).

Finley, Moses I. 1965. "Debt-Bondage and the Problem of Slavery," in M. I. Finley, Economy and Society in Ancient Greece. London: Chatto \& Windus. 1981: 150-66. (Originally published in 43 Revue historique de droit français e étranger 1965: 159-84).

Hansmann, Henry, and Marina Santilli. 1997. "Authors' and Artists' Moral Rights: A Comparative Legal and Economic Analysis,” 26 Journal of Legal Studies 95-143.

Hansmann, Henry, and Marina Santilli. 2001. "Royalties for Artists Versus Royalties for Authors and Composers," 5 Journal of Cultural Economics 259-81.

Hansmann, Henry, and Reinier Kraakman. 2000. "The Essential Role of Organizational Law," 110 Yale Law Journal 387-440.

Hansmann, Henry, and Reinier Kraakman. 2002. "Property, Contract, and Verification: The Numerus Clausus Problem and the Divisibility of Rights," 31 Journal of Legal Studies (issue 2, Pt 2) S373-S420.

Heller, Michael A. 1998. "The Tragedy of the Anticommons: Property in the Transition from Marx to Markets," 111 Harvard Law Review 621-88.

Heller, Michael A. 1999. “The Boundaries of Private Property," 108 Yale Law Journal 1163-223.

Heller, Michael A., and Rebecca S. Eisenberg. 1998. "Can Patents Deter Innovation? The Anticommons in Biomedical Research," 280 Science 698-701.

HMLR (Her Majesty Land Registry). 1996. "Registration of Title to Land: Its Characteristics and Advantages," Explanatory Leaflet 1, January, London: HMLR.

Hoebel, E. Adamson. 1979. The Law of Primitive Man: A Study in Comparative Legal Dynamics. New York: Atheneum. (First ed. Cambridge: Harvard University Press, 1954).

Hosmer, Jr., David W., and Stanley Lemeshow. 2000. Applied Logistic Regression (2nd ed. New York: Wiley).

HUD (United States Department of Housing and Urban Development). 2000. "Buying Your Home: Settlement Cost and Useful Information," Washington, DC: HUD (http://www.hud.gov/fha/sfh/res/sfhrestc.html, accessed June 3, 2001).

ICANN (Internet Corporation for Assigned Names and Numbers). 1999. "Uniform Domain-Name Dispute-Resolution Policy," August 26 (http://www.icann.org/udrp/udrp.htm, accessed November 12, 2001). 
Jackson, Thomas C. 1908. Justinian's Digest (Book 20) with an English Translation and an Essay on the Law of Mortgage in the Roman Law. London: Sweet and Maxwell.

Janczyk, Joseph T. 1977. "An Economic Analysis of the Land Systems for Transferring Real Property," 6 Journal of Legal Studies 213-33.

Janczyk, Joseph T. 1979. "Land Title Systems, Scale of Operations, and Operating and Conversion Costs," 8 Journal of Legal Studies 569-83.

Johnson, Harry M. 1966. “The Nature of Title Insurance," 33 Journal of Risk and Insurance 393410.

Kaplow, Louis, and Steven Shavell. 1995. "Do Liability Rules Facilitate Bargaining? A Reply to Ayres and Talley," 105 Yale Law Journal 221-33.

Kaplow, Louis, and Steven Shavell. 1996. "Property Rules versus Liability Rules: An Economic Analysis," 109 Harvard Law Review 713-90.

Kohler, Jürgen. 1996. "The Law of Rights in Rem," in W. F. Ebke and M. W. Finkin, eds., Introduction to German Law. The Hague: Kluwer, 227-50.

Kolbert, Colin F., and Norman A. M. Mackay. 1977. History of Scots and English Land Law (based on The Principles of Scots and English Land Law by Charles d'Olivier Farran). Berkhamsted: Geographical Publications.

Konig, David T. 1974. "Community Custom and the Common Law: Social Change and the Development of Land Law in Seventeenth-Century Massachusetts," 18 The American Journal of Legal History 137-77.

Kraakman, Reinier H. 1986. "Gatekeepers: The Anatomy of a Third-Party Enforcement Strategy," 2 Journal of Law, Economics and Organization 53-105.

La Porta, Rafael, Florencio Lopez-De-Silanes, Andrei Shleifer, and Robert. W. Vishny. 1999. "The Quality of Government," 15 Journal of Law, Economics and Organization 222-79.

Laffont, Jean-Jacques, and Jean Tirole. 1993. A Theory of Incentives in Procurement and Regulation. Cambridge: The MIT Press.

Larson, Janelle B.M., Theodosios Palaskas, and Godfrey Tyler. 1999. "Land Titling and Technical Efficiency among Small Coffee Producers in Honduras," 20 Canadian Journal of Development Studies 361-82.

Levmore, Saul. 1987. "Variety and Uniformity in the Treatment of the Good-Faith Purchaser," 16 Journal of Legal Studies 43-65.

Levy, Brian, and Pablo T. Spiller. 1994. "The Institutional Foundations of Regulatory Commitment: A Comparative Analysis of Telecommunications Regulation," 10 Journal of Law, Economics, and Organization 201-46.

Lipshutz, Nelson R. 1994. The Regulatory Economics of Title Insurance. Westport: Praeger.

Lowie, Robert H. 1920. Primitive Society, Liveright Pub. Corp., New York, 1947. (First ed. New York: Boni and Liveright, 1920).

Manning, Joe G. 1995. "Demotic Egyptian Instruments of Transfer as Evidence for Private Ownership of Real Property," 71 Chicago-Kent Law Review 237-68. 
Manning, Joe G. 2003. "Private Property Rights and the Conveyance of Land: Property Rights in Land under the Ptolemies - Documentary evidence for Conveyances-Upper Egyptian conveyance of Land State Regulation of Conveyance," Stanford University, draft, forthcoming as Chapter 6 in J. G. Manning, Land and Power in Ptolemaic Egypt: The Structure of Land Tenure 332-30 BCE. Cambridge: Cambridge University Press.

MCA (Massachusetts Conveyancers Association). 2001. "Deregistration Bill Passes," 20 The Conveyancer, Newsletter of the Massachusetts Conveyancers Association (http://www.massconveyancers.org/newsletters/winter01/deregistration.htm, accessed May 4, 2002).

McCormack, John L. 1992. "Torrens and Recording: Land Title Assurance in the Computer Age," 18 William Mitchell Law Review 61-129.

McDougal, Myres S., and John W. Brabner-Smith. 1939. "Land Title Transfer: A Regression," 48 Yale Law Journal 1125-51.

Merrill, Thomas W., and Henry E. Smith. 2000. "Optimal Standardization in the Law of Property: The Numerus Clausus Principle," 110 Yale Law Journal 1-70.

Merrill, Thomas W., and Henry E. Smith. 2001a. "The Property/Contract Interface," 101 Columbia Law Review 773-852.

Merrill, Thomas W., and Henry E. Smith. 2001b. "What Happened to Property in Law and Economics?," 111 Yale Law Journal 357-98.

Miceli, Thomas J., and C. F. Sirmans. 1995. "The Economics of Land Transfer and Title Insurance," 10 Journal of Real Estate Finance and Economics 81-88.

Miceli, Thomas J., C. F. Sirmans, and Geoffrey K. Turnbull. 1998. "Title Assurance and Incentives for Efficient Land Use," 6 European Journal of Law Economics 305-23.

Miceli, Thomas J., C. F. Sirmans, and Geoffrey K. Turnbull. 2000. "The Dynamic Effects of Land Title Systems," 47 Journal of Urban Economics 370-89.

Miceli, Thomas J., C. F. Sirmans, and Joseph Kieyah. 2001. "The Demand for Land Title Registration: Theory with Evidence from Kenya," 3 American Law and Economics Review 275-87.

Miceli, Thomas J., Henry Munneke, C. F. Sirmans, and Geoffrey K. Turnbull. 2002. "Title Systems and Land Values," 45 Journal of Law and Economics 565-82.

Mueller, Milton. 2001. "Rough Justice: An Analysis of ICANN's Uniform Dispute Resolution Policy," Syracuse University School of Information Studies, Center for Science and Technology, November 9 (http://dcc.syr.edu/roughjustice.pdf, accessed November 18, 2001).

North, Douglas C., and Robert P. Thomas. 1973. The Rise of the Western World: A New Economic History. Cambridge: Cambridge University Press.

North, Douglass C. 1990. Institutions, Institutional Change and Economic Performance. Cambridge: Cambridge University Press.

Nyce, Charles, and M. Martin Boyer. 1998. "An Analysis of the Title Insurance Industry," 17 Journal of Insurance Regulation 213-56.

O'Connor, Pamela. 2003. "Registration of Title in England and Australia: A Theoretical and Comparative Analysis," forthcoming in E. Cooke, ed., Modern Studies in Property Law, vol. 2. Oxford: Hart Publishing Ltd, 81-99. 
Oliver y Esteller, Bienvenido. 1892. Derecho inmobiliario español: Exposición fundamental y sistemática de la Ley Hipotecaria, vol. 1. Madrid: Sucesores de Rivadeneyra.

Palomar, Joyce D. 2000. Title Insurance Law. St. Paul: West. (First ed., 1994. Last revised: July 6, 2000).

Patault, Anne-Marie. 1989. Introduction historique au droit des biens. Paris: Presses Universitaires de France.

Picod, Yves. 1999. Sûretés: Publicité foncière, 7th ed., in H. Mazeaud, L. Mazeaud, J. Mazeaud and F. Chabas, eds., Leçons de Droit Civil, tome 3, vol. 1. Paris: Montchrestien.

Piedelièvre, Stéphane. 2000. La publicité foncière. Paris: Librairie Général de Droit et Jurisprudence.

Place, Frank, and Peter Hazell. 1993. "Productivity Effects of Indigenous Land Tenure Systems in Sub-Saharan Africa," 75 American Journal of Agricultural Economics 10-19.

Place, Frank, and Shem E. Migot-Adholla. 1998. "The Economic Effects of Land Registration on Smallholder Farms in Kenya: Evidence from Nyeri and Kakamega Districts," 74 Land Economics 360-73.

Polanyi, Karl. 1944. The Great Transformation: The Political and Economic Origins of Our Time. Boston: Beacon Hill.

Posner, Eric A., Richard Hynes, and Anup Malani. 2001. "The Political Economy of Property Exemption Laws," Law School, University of Chicago, John M. Olin Law \& Economics Working Paper 136 (http://www.law.uchicago.edu/Lawecon/index.html, accessed May 26, 2002).

Pottage, Alain. 1998. "Evidencing Ownership," in S. Bright and J. Dewar, eds., Land Law: Themes and Perspectives. Oxford and New York: Oxford University Press, 129-50.

Powell, Richard R. B. 1938. Registration of the Title to Land in the State of New York. Rochester: Lawyers Co-Operative Publishing Company.

Powelson, John P. 1988. The Story of Land: A World History of Land Tenure and Agrarian Reform. Cambridge: Lincoln Institute of Land Policy.

Rose, Carol M. 1988. "Crystals and Mud in Property Law," 40 Stanford Law Review 577-610.

Sarton, Priscilla. 2000. Conveyancing, 3rd ed. London: Macmillan.

Shavell, Steven. 1997. "The Fundamental Divergence between the Private and the Social Motive to Use the Legal System," 26 Journal of Legal Studies 575-612.

Shick, Blair C., and Irving H. Plotkin. 1978. Torrens in the United States: A Legal and Economic Analysis of American Land Registration Systems. Lexington, MA, and Toronto: D.D. Heath and Co.

Silver, Morris. 1995. Economic Structures of Antiquity, Contributions in Economics and Economic History 159. Westport: Greenwood Press.

Silverman, Frances. 2001. Conveyancing Handbook 2001, 8th ed. London: Law Society Publishing.

Sparkes, Peter. 1999. A New Land Law. Oxford and Portland: Hart Publishing.

Stein, Robert T. J., and Margaret A. Stone. 1991. Torrens Title. Sidney: Butterworths. 
Straw, Jr., Ralph L. 1967. "Off-Record Risks for Bona Fide Purchasers of Interests in Real Property," 72 Dickinson Law Review 35-90.

Suleiman, Ezra N. 1987. Private Power and Centralization in France: The Notaries and the State. Princeton: Princeton University Press.

Troister, Sidney H., and Kathleen A. Waters. 1996. "Real Estate Conveyancing in Ontario: A Nineties Perspective," mimeo, Lawyers' Professional Indemnity Company.

UN-ECE (United Nations Economic Commission for Europe). 2000. Study on Key Aspects of Land Registration and Cadastral Legislation. London: HMLR.

Villani, Kevin, and John Simonson. 1982. "Real Estate Settlement Pricing: A Theoretical Framework," 10 American Real Estate and Urban Economics Association Journal 249-75.

Watson, Alan. 1984. The Law of Property in the Later Roman Republic, Aalen, Germany: Scientia. (First ed. Oxford: Oxford University Press, 1968).

Weill, Alex. 1979. Droit civil: Les sûretés, la publicité foncière. Paris: Dalloz.

Whalan, Douglas J. 1982. The Torrens System in Australia. Sidney: Law Book Company.

Williamson, Oliver E. 1976. "Franchise Bidding for Natural Monopoly-In General and with Respect to CATV," 7 The Bell Journal of Economics 73-107.

World Bank. 2001. "Land Policy and Administration: Lessons Learned and New Challenges for the World Bank's Development Agenda," Background Paper for the On-line Conference on Land Policy. Washington: World Bank

(http://wbln0018.worldbank.org/essd/rdv/vta.nsf/Gweb/landpolicy, accessed June 2, 2001). 


\section{Figure 1. Comparison of privacy, recording and registration}

Explanatory note: broken lines represent information flows; continuous lines, alternative parties' decisions with respect to demanding a report on title, purging contradictory rights and keeping evidence out of the chain of title, as well as the registration judgment.

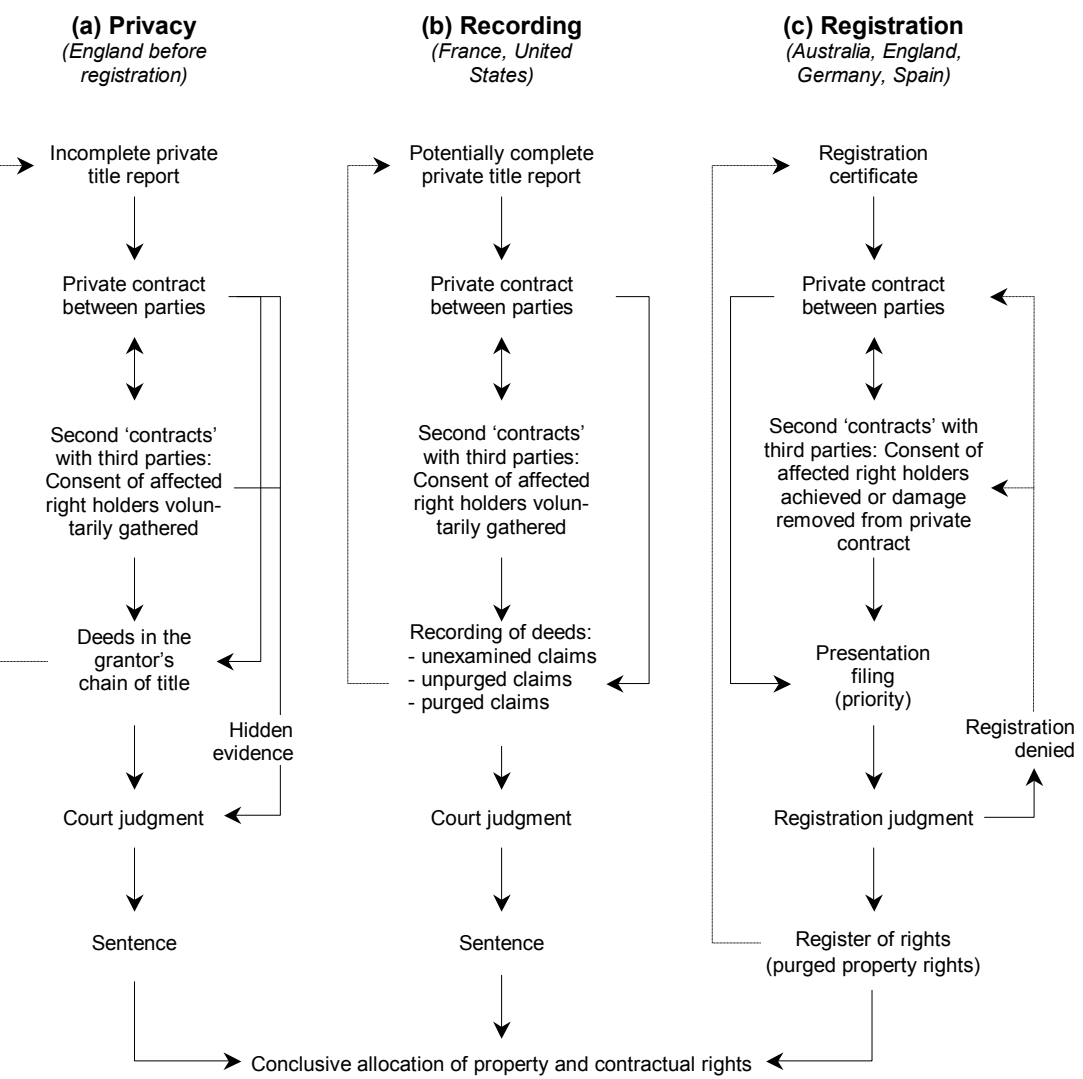


Table 1. Number of registerable property rights in $\mathbf{4 2}$ jurisdictions

\begin{tabular}{|c|c|c|c|c|c|c|}
\hline \multirow{3}{*}{ Independent variables } & \multicolumn{6}{|c|}{ Dependent variables } \\
\hline & \multicolumn{4}{|c|}{ Number of Property Rights } & \multicolumn{2}{|c|}{ Recording } \\
\hline & $(1)$ & (2) & (3) & (4) & $(5)$ & (6) \\
\hline Recording & $\begin{array}{l}13.387^{* * *} \\
(2.641)\end{array}$ & $\begin{array}{l}11.412^{* * *} \\
(2.474)\end{array}$ & $\begin{array}{l}11.945^{* * *} \\
(2.485)\end{array}$ & $\begin{array}{l}10.525^{* * *} \\
(2.569)\end{array}$ & & \\
\hline Effects of Filing & & $\begin{array}{l}-13.205^{* * *} \\
(4.223)\end{array}$ & $\begin{array}{l}-11.310^{* *} \\
(4.199)\end{array}$ & $\begin{array}{l}-9.385^{* *} \\
(4.226)\end{array}$ & & \\
\hline \multicolumn{7}{|l|}{$\begin{array}{l}\text { Legal Origin (omitted category, } \\
\text { English Common Law): }\end{array}$} \\
\hline - Civil Law: & & & $\begin{array}{l}-0.921 \\
(2.680)\end{array}$ & & $\begin{array}{l}1.017 \\
(0.619)\end{array}$ & \\
\hline French Law & & & & $\begin{array}{l}2.931 \\
(3.326)\end{array}$ & & $\begin{array}{l}1.654^{* *} \\
(0.696)\end{array}$ \\
\hline German Law & & & & $\begin{array}{l}-2.978 \\
(4.233)\end{array}$ & & \\
\hline Scandinavian Law & & & & $\begin{array}{l}-4.350 \\
(3.526)\end{array}$ & & $\begin{array}{l}0.494 \\
(0.830)\end{array}$ \\
\hline - Socialist Law & & & $\begin{array}{l}-5.059^{*} \\
(2.705)\end{array}$ & $\begin{array}{l}-4.984^{*} \\
(2.646)\end{array}$ & $\begin{array}{l}0.712 \\
(0.634)\end{array}$ & $\begin{array}{l}0.712 \\
(0.634)\end{array}$ \\
\hline Constant & $\begin{array}{l}7.613^{* * *} \\
(1.352)\end{array}$ & $\begin{array}{l}20.392^{* * *} \\
(4.266)\end{array}$ & $\begin{array}{l}20.651^{* * *} \\
(4.364)\end{array}$ & $\begin{array}{l}19.029^{* * *} \\
(4.349)\end{array}$ & $\begin{array}{l}-1.335^{* *} \\
(0.530)\end{array}$ & $\begin{array}{l}-1.335^{* *} \\
(0.530)\end{array}$ \\
\hline Observations & 42 & 42 & 42 & 42 & 42 & 39 \\
\hline$R$-squared ${ }^{\text {a }}$ & 0.39 & 0.51 & 0.56 & 0.61 & 0.06 & 0.14 \\
\hline \multicolumn{7}{|l|}{ Wald tests: } \\
\hline $\begin{array}{l}\text { Civil Law }=\text { Socialist Law } \\
\text { Prob }>F^{\text {a }}\end{array}$ & & & $\begin{array}{l}2.89 \\
0.0976\end{array}$ & & $\begin{array}{l}0.42 \\
0.5190\end{array}$ & \\
\hline $\begin{array}{l}\text { French Law = German Law } \\
\quad \text { Prob }>F\end{array}$ & & & & $\begin{array}{l}1.57 \\
0.2191\end{array}$ & & \\
\hline $\begin{array}{l}\text { French Law }=\text { Scandinavian Law } \\
\quad \text { Prob }>F^{\text {a }}\end{array}$ & & & & $\begin{array}{l}3.42 \\
0.0730\end{array}$ & & $\begin{array}{l}2.20 \\
0.1380\end{array}$ \\
\hline $\begin{array}{l}\text { French Law }=\text { Socialist Law } \\
\quad \text { Prob }>F^{\text {a }}\end{array}$ & & & & $\begin{array}{l}6.49 \\
0.0154\end{array}$ & & $\begin{array}{l}2.73 \\
0.0984\end{array}$ \\
\hline $\begin{array}{l}\text { German Law }=\text { Scandinavian Law } \\
\quad \text { Prob }>F\end{array}$ & & & & $\begin{array}{l}0.08 \\
0.7745\end{array}$ & & \\
\hline $\begin{array}{l}\text { German Law }=\text { Socialist Law } \\
\quad \text { Prob }>F\end{array}$ & & & & $\begin{array}{l}0.23 \\
0.6315\end{array}$ & & \\
\hline $\begin{array}{l}\text { Scandinavian Law }=\text { Socialist Law } \\
\quad \text { Prob }>F^{\mathrm{a}}\end{array}$ & & & & $\begin{array}{l}0.04 \\
0.8505\end{array}$ & & $\begin{array}{l}0.09 \\
0.7637\end{array}$ \\
\hline
\end{tabular}

Notes: Models (1) to (4), OLS; (5) and (6), probit regression. Standard errors in parentheses.

${ }^{*},{ }^{* *},{ }^{* * *}$ Significant at 10, 5 and 1\%. ${ }^{a}$ Pseudo R-squared and Prob $>C h i^{2}$ in models (5) and (6). 